\title{
$\begin{array}{lllllllllllllllll}\mathbf{R} & \mathbf{O} & \mathbf{Z} & \mathbf{P} & \mathbf{R} & \mathbf{A} & \mathbf{W} & \mathbf{Y} & \text { I } & \text { A } & \mathbf{R} & \mathbf{T} & \mathbf{Y} & \mathbf{K} & \mathbf{U} & \mathbf{L} & \mathbf{Y}\end{array}$
}

Prawo Kanoniczne

$61(2018) \mathrm{nr} 4$

DOI:10.21697/pk.2018.61.4.01

KS. JERZY ADAMCZYK

Wyższe Seminarium Duchowne w Radomiu

\section{STATUTY KAPITUŁ KANONICKICH}

Treść: Wstęp. - 1. Statut jako akt normatywny w ogólności. - 2. Walor prawny statutów kapituły. - 3. Treść statutów kapituł kanonickich. - Podsumowanie.

\section{Wstęp}

Kapituła kanoników jest to kolegium duchownych ustanowione w celu wykonywania uroczystego kultu Bożego w kościele katedralnym lub kolegiackim ${ }^{1}$. Początków kapituł można dopatrywać się w prezbiterium, czyli kolegium kapłanów (w liczbie dwunastu) i siedmiu diakonów miasta biskupiego, które od najdawniejszych czasów istnienia Kościoła otaczało biskupa, wspierając go w zarządzie diecezją radą i pomocą. Wewnętrzna organizacja kapituł ukształtowała się w oparciu o regułę życia wspólnego ułożoną w połowie VIII wieku (755 r.) przez św. Chrodeganga, biskupa Metzu (742-766 r.), przepracowaną przez diakona Amalariusza z Metzu (+ 850) i usankcjonowaną przez synod akwizgrański w 816 r., który ją potwierdził i polecił wprowadzić w życie przy wszystkich kościołach, przy których nie było zakonników ${ }^{2}$

\footnotetext{
${ }^{1}$ Codex Iuris Canonici. Auctoritate Ioannis Pauli PP. II promulgatus. Kodeks Prawa Kanonicznego, przekład polski zatwierdzony przez Konferencję Episkopatu, Poznań 1984, kan. 503, (odtąd: KPK). Ponadto kapituła katedralna wypełnia zadania zlecone jej przez prawo lub przez biskupa diecezjalnego. Kan. 503.

${ }^{2}$ Por. F. Bączkowicz, J. Baron, W. Stawinoga, Prawo kanoniczne. Podręcznik dla duchowieństwa, t. 1, Opole 1957, s. 541-542; W. GAŁĄzKA, Kapituła Kolegiacka w Opatowie w latach 1562-1983, Sandomierz 1997, s. 23; H. CAppello, Los Cabildos de
} 
Kapituła może być katedralna, albo kolegiacka, zależnie od rangi kościoła, przy którym istnieje ${ }^{3}$. Kapituły istniejące przy katedrach biskupich odegrały dużą rolę w życiu Kościoła. Aktualny Kodeks prawa kanonicznego, mimo znacznego ograniczenia funkcji kapituł katedralnych na rzecz rady kapłańskiej, zachował te czcigodne gremia, poświęcając im aż osiem kanonów ${ }^{4}$, choć liczba tych przepisów została wyraźnie zmniejszona w stosunku do KPK z 1917 r. ${ }^{5}$

Zgodnie z kan. 505 każda kapituła, tak katedralna, jak i kolegiacka jako osoby prawne, powinny mieć własne statuty jako prawo własne i wewnętrzne, sporządzone zgodnym z prawem aktem kapitulnym i zatwierdzone (approbatio) przez biskupa diecezjalnego ${ }^{6}$.

Zagadnienie statutu kapituł kanonickich zostanie zaprezentowane w trzech częściach: w pierwszej omówi się kwestię statutu jako aktu normatywnego w ogólności, następnie ukaże się walor prawny statutów kapituły, z kolei zostanie przedstawiona treść wspomnianych dokumentów ${ }^{7}$. Rozważania niniejszego przedłożenia mają być przyczynkiem do ukazania kwestii statutów kapituł kanoników, będących prawem własnym i wewnętrznym tych osób prawnych. Należy dodać,

Canónigos. Pasado, presente y futuro de los mismos, Anuario Argentino de Derecho Canónico 21(2015), s. 394.

${ }^{3}$ Jeśli kapituła ma swoją siedzibę w kościele katedralnym, nazywa się ją kapitułą katedralną; jeśli nie, to kapitułą kolegiacką (i odpowiedni kościół nazywa się kolegiatą). Por. G. Bier, Cabildo de canónigos, w: Diccionario General de Derecho Canónico, Obra dirigida y coordinada por J. Otaduy, A.Viana, J. Sedano, vol. I, Editorial Aranzadi, Pamplona 2012, s. 781.

${ }^{4}$ Kan. 503-510.

${ }^{5}$ Por. H. Cappello, Los Cabildos de Canónigos, s. 396.

${ }^{6}$ Statuty kapituł uzyskują moc obowiązującą z chwilą zatwierdzenia przez biskupa diecezjalnego.

${ }^{7} \mathrm{~W}$ artykule nie będą brane pod uwagę ewentualne regulaminy kapituł, w których przewidzianoby bardziej szczegółowe kwestie dotyczące sposobu funkcjonowania kapituły. Por. Congregaticio Pro EpIscopis, Direttorio per il ministero pastorale dei vescovi [22 febbraio 2004], nr 187, Città del Vaticano 2004, tekst polski: KonGREgACJA Do SPRAw BIskupów, Dyrektorium o pasterskiej posłudze biskupów "Apostolorum Successores", Kielce 2005 (odtąd: AS). 
że zagadnienie to nie było dotychczas podejmowane, jako osobne opracowanie, na gruncie kanonistyki.

\section{Statut jako akt normatywny w ogólności}

Pojecie statut zarówno w obszarze kanonicznym, jak i cywilnym ma różne znaczenia, które jednak można sprowadzić do jednego: statuty to zespół norm, dyspozycji i praw ${ }^{8}$. Statut to zbiór przepisów (ordinationes) wydawanych zgodnie z przepisami prawa dla zrzeszeń (wspólnot) obejmujących osoby, albo dla zespołów rzeczy, określające ich cel, strukturę, zarząd i sposoby działania ${ }^{9}$. Celem i treścią tak rozumianych statutów jest określenie ad normam iuris celów, struktury, zarządu i działalności wyżej wymienionych instytucji czy podmiotów ${ }^{10}$. Terminem statuty określa się normy materialnie dotyczące organizacji i funkcjonowania instytucji lub podmiotu. Pod względem formalnym statuty są dokumentami, które zawierają wspomniane normy ${ }^{11}$. Część wstępna statutu czasami nawiązuje do powstania danej instytucji oraz krótko ukazuje jej działalność $\mathrm{w}$ aspekcie historycznym ${ }^{12}$.

Kościelne osoby prawne i inne jednostki organizacyjne rządzą się nie tylko ustawami, lecz także opartymi na nich statutami. Ustawa zazwyczaj zawiera ramowe (ogólne) przepisy dotyczące danej osoby prawnej lub instytucji, natomiast statut jest zbiorem przepisów szczegółowych ${ }^{13}$.

Normy o statutach i przepisach porządkowych zawarte są w księdze I, tytule V Kodeksu prawa kanonicznego z 1983 r. Tytuł ten jest nowy, bowiem w KPK z 1917 r. norm odnoszących się do statutów nie

\footnotetext{
${ }^{8}$ Por. L. Chiappetta, Il Codice di Diritto Canonico, t. 1, wyd. 1, Napoli 1988, s. 111.

${ }^{9}$ Por. E. Sztafrowski, Podręcznik prawa kanonicznego, t. 1, Warszawa 1985, s. 210.

${ }^{10}$ Por. L. Chiappetta, Il Codice di Diritto Canonico, s. 111.

${ }^{11}$ A. Bettetini, Comentario al can. 94, w: Comentario exegético al Código de Derecho Canónico, pod red. A. Marzoa, J. Miras, R. Rodríguez-Ocaña, t. 3, cz. I, wyd. 2, Pamplona 1996, s. 708.

${ }^{12}$ Por. T. Pawluk, Prawo kanoniczne według Kodeksu Jana Pawła II. Zagadnienia wstępne i normy ogólne, t. 1, Olsztyn 1985, s. 248.

${ }^{13}$ Por. tamże, s. 247-248.
} 
rozpatrywano osobno, lecz wspominano o nich w różnych miejscach tego zbioru ${ }^{14}$.

Statuty są obok ustaw, prawa zwyczajowego, dekretów wykonawczych i instrukcji formalnymi - wtórnymi - źródłami prawa. Są one prawem kościelnym ${ }^{15}$. Jeśli są stanowione autonomicznie przez odnośne zespoły, zwykło się zaliczać je do tzw. ius secundarium. Prace nad kanonami dotyczącymi statutów i przepisów porządkowych miały pierwotnie na względzie jedynie osoby prawne i stowarzyszenia, potem jednak uwzględniono istnienie także innych zespołów osób kierujących się swymi statutami, jak np. - z jednej strony - konferencje biskupów czy kapituły oraz - z drugiej strony stowarzyszenia bez osobowości prawnej ${ }^{16}$.

Kan. $94 \$ 1 \mathrm{KPK}$ zawiera następującą definicję statutów: „statuty w sensie właściwym oznaczają zarządzenia wydawane zgodnie z prawem w zespołach osób lub rzeczy, a określające ich cel, konstytucję, zarząd i sposoby działania"17. Na równi z nazwą „statut” stosuje się w KPK terminy ius proprium ${ }^{18}$, constitutiones ${ }^{19}$, ordinatio ${ }^{20}$, a nawet lex ${ }^{21}$.

${ }^{14}$ W sposób szczególny Codex Iuris Canonici, Pii X Pontificis Maximi iussu digestus Benedicti Papae XV auctoritate promulgatus, Romae 1951 uwzględniał statuty w następnych kanonach: $395 \$ 4,397,410,411 \S 2,416,417 \S 2,418 \S 1,422 \S 2,689$, $715 \$ 1,1376 \$ 2$. Por. X. Brossa, Régimen jurídico de los santuarios en el CIC, Roma 1996, s. 202; A. Bettetini, Comentario al can. 94-95, s. 705.

${ }^{15}$ Niektórzy kanoniści normy statutowe nazywają „prawem statutowym”, jak np. Jiménez Urresti, Comentario a los cán. 1-123, w: Código de Derecho Canónico, Edición bilingüe comentada por los Profesores de la Facultad de Derecho Canónico de la Universidad Pontificia de Salamanca, Madrid 1983, s. 75; por. P. MarcuzzI, Statuti e regolamenti, Apollinaris 60(1987), nr 3-4, s. 538.

${ }^{16}$ Por. R. Sobański, Komentarz do kan. 94, w: Komentarz do Kodeksu Prawa Kanonicznego. T. 1. Ks. 1. Normy ogólne, J. Krukowski (red.), Poznań 2003, s. 160.

${ }^{17}$ R. SobAŃsKi stwierdza, że sporne jest, czy w kan. $94 \$ 1$ przytoczonego kanonu podano definicję statutów czy tylko wyjaśnienie ich pojęcia. Komentarz do kan. 94, s. 161.

${ }^{18} \mathrm{Kan} .307 \$ 3 ; 597 \$ 1 ; 598 \$ 2 ; 600 ; 607 \$ 2 ; 616 \S 1$.

${ }^{19}$ Kan. 581; $587 \S 1 ; 595 ; 596 \$ 1 ; 598 \$ 1 ; 601$.

${ }^{20}$ Kan. 243; 261; $543 \$ 1$.

${ }^{21}$ Kan. $573 \S 2$; 619; por. R. SobAŃsKi, Komentarz do kan. 94, s. 161. 
Ustawodawca przyznaje określonym podmiotom (korporacjom i fundacjom) uprawnienia normatywne do ustalania zasad ich organizacji lub sposobu funkcjonowania. W związku z tym, pewne podmioty cieszą się autonomią statutową, to znaczy mogą posiadać normy w ramach ich własnej organizacji ${ }^{22}$. Statuty stanowią własne przepisy określonego podmiotu. Wypracowywanie statutów jest osobistym (własnym), autonomicznym aktem konkretnej instytucji. Jest aktem posiadającym treść normatywną, różnym od aktu ustanowienia instytucji, chociaż może urzeczywistniać się jednocześnie z nim. Z punktu widzenia materialnego statuty są normami, odnoszącymi się do organizacji i sposobu działania instytucji albo podmiotu; formalnie są dokumentem, który zawiera takie normy ${ }^{23}$.

Co do podmiotów, które posiadają „potestas statuendi” warto podkreślić, że w fazie opracowania kan. 94 poszerzono instytucje, które miały taką możliwość. Najpierw chodziło tylko o stowarzyszenia i osoby prawne, natomiast $\mathrm{w}$ redakcji ostatecznej uwzględniono także korporacje i fundacje ${ }^{24}$. W ten sposób uwzględniono inne podmioty (instytucje), nie mające natury zrzeszeniowej (asocjacyjnej), których działanie może, czy powinno być regulowane przez statuty (konferencje biskupie, kapituły, ordynariaty wojskowe, itd.), jak również podmioty bez osobowości prawnej ${ }^{25}$.

W rezultacie KPK ustala, że bardzo odmienne podmioty, spełniające ogólne warunki i formy korporacji i fundacji, powinny lub mogą posiadać swoje statuty: osoby prawne w ogólności ${ }^{26}$, seminaria duchowne ${ }^{27}$, stowarzyszenia prywatne bez osobowości prawnej ${ }^{28}$,

\footnotetext{
${ }^{22}$ Por. X. Brossa, Régimen jurídico, s. 202-203; A. Bettetini, Comentario al can. 94, s. 709.

${ }^{23}$ Por. X. Brossa, Régimen jurídico, s. 203.

${ }^{24}$ Por. Communicationes 14 (1982), s. 138-139; X. Brossa, Régimen jurídico, s. 203.

${ }^{25}$ Por. X. Brossa, Régimen jurídico, s. 203; R. Sobański, Komentarz do kan. 94, s. 160; P. MarcuzzI, Statuti e regolamenti, s. 537.

${ }^{26}$ Kan. 117.

${ }^{27}$ Kan. 237; 239 § 3.

${ }^{28}$ Kan. $299 \$ 3$.
} 
stowarzyszenia publiczne i prywatne ${ }^{29}$, konferencje biskupie ${ }^{30}$, rada kapłańska ${ }^{31}$, kapituły ${ }^{32}$, diecezjalna rada duszpasterska ${ }^{33}$, konferencje wyższych przełożonych ${ }^{34}$, uniwersytety katolickie ${ }^{35}$, uniwersytety i fakultety kościelne ${ }^{36}$, sanktuaria ${ }^{37}$ itd..$^{38}$. Jeśli chodzi o przepisy wewnętrzne (statuty) instytutów życia konsekrowanego i stowarzyszeń życia apostolskiego, to KPK nazywa je konstytucjami albo kodeksem fundamentalnym, gdzie zawarte są normy podstawowe określonego instytutu ${ }^{39}$.

Warto zauważyć, że określone różnice w ramach ogólnych przepisów o statutach dotyczą obowiązku albo stosowności przygotowania statutów, spraw, które powinny obejmować, zadania władzy kościelnej (czy winna aprobować albo jedynie przejrzeć statuty, które jej się przedstawia, lub czy ma ona prawo nadawać statuty), funkcjonowania instytucji albo podmiotów, których organizację regulują ${ }^{40}$.

Statuty są wydawane w zespołach osób lub rzeczy, które mogą w ramach obowiązującego, nadrzędnego prawa - decydować o swoich sprawach wewnętrznych. Zgodnie ze swymi statutami winny działać wszystkie osoby prawne, zarówno zespoły osób, jak i rzeczy ${ }^{41}$.

\footnotetext{
${ }^{29}$ Kan. $304 \$ 1,314$ i $322 \$ 2$.

${ }^{30}$ Kan. 451.

${ }^{31}$ Kan. 496.

${ }^{32}$ Kan. 505.

${ }^{33}$ Kan. $513 \$ 1$.

${ }^{34}$ Kan. 709.

${ }^{35}$ Kan. $810 \$ 1$.

${ }^{36}$ Kan. $816 § 2$.

${ }^{37}$ Kan. 1232; por. X. BrossA, Régimen jurídico, s. 204.

${ }^{38}$ Zob. P. MarcuzzI, Statuti e regolamenti, s. 538-539.

${ }^{39}$ Kan. 587 \$1; por. kan. 732; X. BrossA, Régimen jurídico, s. 204; L. ChiappetTA, Il Codice di Diritto Canonico, s. 111.

${ }^{40}$ Por. X. Brossa, Régimen jurídico, s. 204; P. Marcuzzi, Statuti e regolamenti, S. 540 .

${ }^{41}$ R. SobAŃski zauważa, że „stwierdzenie [kan. $94 \$ 1$ ], że statuty są «wydawane w zespołach» jest nieprecyzyjne, gdyż statuty mogą też być nadawane przez zewnętrzne podmioty władzy, czy to ustawodawczej, czy to wykonawczej. Jeśli statuty
} 
Kanon $94 \$ 1$ zawiera ważne sformułowanie: „statuty w sensie właściwym” (statuta sensu proprio) - nad którym warto się zatrzymać i rozważyć je w powiązaniu z $\$ 3$ tego kanonu. Ze względu na dużą pojemność (szerokość) terminu „statuty”, prawodawca chciał określić, że statutami w sensie właściwym (prawnie) są te, które definiuje kan. $94 \$ 1^{42}$. Istotnie, ustawodawca uznaje - i takie samo stanowisko zajmuje doktryna - istnienie statutów w sensie właściwym jako przepisów prawnych wewnętrznych, w odróżnieniu od innych norm statutowych, które mają moc ustawy. Te ostatnie nadawane są przez zewnętrzne podmioty władzy, czy to ustawodawczej (niższej od władzy najwyższej), czy to wykonawczej ${ }^{43}$. Jeśli statuty zostały nadane mocą władzy ustawodawczej, kierują się przepisami o ustawach ${ }^{44}$.

P. Marcuzzi ${ }^{45}$ zauważa, że to, co jest przewidziane w kan. $94 \$ 3$ pokazuje, iż statuty jako całość lub przepisy w statucie mogą przyjąć formę autentycznej ustawy kościelnej. Warunkiem tego jest, aby były one tworzone i ogłaszane na mocy władzy ustawodawczej. Nie

zostały nadane mocą władzy ustawodawczej, kierują się przepisami o ustawach”. Komentarz do kan. 94, s. 161; zob. P. MARCuzzI, Statuti e regolamenti, s. 538.

${ }^{42}$ Statuty w sensie właściwym są przepisami własnymi stowarzyszeń, podmiotów, instytucji i fundacji, istniejących w Kościele. Por. Communicationes 3 (1971), s. 93, nr 6 a; L. Chiappetta, Il Codice di Diritto Canonico, s. 111; zob. P. Marcuzzi, Statuti e regolamenti, s. 536-537.

${ }^{43} \mathrm{~W}$ aktualnym porządku kanonicznym statut przyjmuje niekiedy szczególne znaczenie prawne, w przypadku, gdy wydany jest przez ustawodawcę niższego od Biskupa Rzymskiego: tak kan. 548 \$1, mówi o „statutach diecezjalnych”, wydanych przez biskupa, któremu powierzone jest zarządzanie Kościołem partykularnym.

${ }^{44} \mathrm{Kan} .94 \$ 3$. Statuty takie mają zatem naturę i moc ustawy i kierują się dyspozycjami kanonów o ustawach (kan. 7-22). W tych wypadkach kompetentna władza kościelna daje albo przyznaje statuty określonemu podmiotowi. Por. X. Brossa, Régimen jurídico, s. 206; R. SobAŃski, Komentarz do kan. 94, s. 161. Te dwie różne kategorie statutów (statuty w sensie właściwym i statuty mające moc ustawy) mają istotne znaczenie zarówno dla celów ustalenia źródła ich obligatoryjności, ich interpretacji, jak i ewentualnej kontroli prawnej. Podstawa obowiązkowego charakteru statutów (statutów normatywnych), o których traktuje kan. $94 \$ 3$ tkwi w suwerenności prawodawcy, w jego potestas regiminis. Por. A. Bettetini, Comentario al can. 94, s. 709 .

${ }^{45}$ Statuti e regolamenti, s. 541-542. 
mówi się: „sporządzane i promulgowane przez tych, którzy posiadają władzę ustawodawczą", z tego prostego powodu, że przygotowanie aktów prawnych wymaga skomplikowanej pracy redakcyjnej, zwykle wykonywanej przez tych, którzy nie mają władzy ustawodawczej, ale działają na jej mocy; nawet promulgacja jest czasami dokonywana przez tych, którzy nie mają władzy ustawodawczej, lecz działają na jej mocy. W pewnym sensie można powiedzieć, że wykonywanie władzy ustawodawczej ma tu miejsce formalnie, gdy organ kolegialny, obdarzony władzą ustawodawczą, przygotowuje zbiorowo projekty ustaw i zatwierdza je w drodze aktu urzędowego. W konsekwencji, jeśli statut lub jego zapisy mają być prawdziwymi ustawami kościelnymi, organizm ustawodawczy musi postępować w ten sam sposób, w jaki tworzy się ustawy kościelne ${ }^{46}$. Z tego powodu kan. 94 $\$ 3$ ustala, że przepisy statutów, ustanowione i promulgowane mocą władzy ustawodawczej, kierują się przepisami kanonów o ustawach. Należy również zwrócić uwagę, że samo zatwierdzenie przez władzę ustawodawczą nie wystarczy, aby tym samym przekształcić statut w ustawę kościelną: zatwierdzenie konstytucji laickiego instytutu życia konsekrowanego przez biskupa lub Stolicę Apostolską nie czyni z nich praw kościelnych, właśnie dlatego, że konstytucje te nie zostały ogłoszone na mocy kościelnej władzy ustawodawczej ${ }^{47}$. Statuty, które są prawdziwymi ustawami kościelnymi to: statuty diecezjalne ${ }^{48}$; statuty kleryckich instytutów zakonnych na prawie papieskim, zwane

\footnotetext{
${ }^{46}$ Kan. 7-21.

${ }^{47}$ Statuty instytucji, czy stowarzyszeń, zwyczajnie, po prostu zatwierdzone przez właściwe władze kościelne, nie mają mocy ustawy (kan. 117; 299 §3;314; 322 \$2; 816 $\$ 2 ; 1232 \$ 1$, itd.). Zatwierdzenie nie zmienia ich charakteru. Natomiast konstytucje kleryckich instytutów zakonnych i stowarzyszeń życia apostolskiego na prawie papieskim są „ustawami”, ponieważ przełożeni, którzy je wydają, są prawdziwymi ordynariuszami (kan. $134 \$ 1$ ), obdarzonymi władzą rządzenia. Por. L. Chiappetta, Il Codice di Diritto Canonico, s. 111.

${ }^{48}$ Kan. $548 § 1$.
} 
kodeksem podstawowym lub konstytucjami ${ }^{49}$; statuty prałatur personalnych ${ }^{50}$; statut ordynariatów wojskowych ${ }^{51}$.

Statuty w sensie właściwym rozpatrywane są w $\$ 1$ i 2 kan. 94 i jest to sytuacja zwyczajna w przypadku większości podmiotów o których mowa w KPK: statuty są ustalane przez właściwe kolegium albo instytucję prawną, i aby miały skutki kanoniczne wymaga się aprobaty albo kontroli (przejrzenia) kompetentnej władzy kościelnej. Podmiot albo instytucja opracowuje lub redaguje statuty i przedstawia je odpowiedniej władzy do aprobaty albo przejrzenia ${ }^{52}$.

Trzeba dodać, że approbatio albo recognitio władzy kościelnej nie zmienia wewnętrznej natury norm statutowych (statuty w sensie właściwym według kan. $94 \$ 1$ ), a zatem nie powoduje, że statuty stają się ustawami kościelnymi ${ }^{53}$.

Zasadnicze cechy charakterystyczne norm statutowych w rozumieniu kan. $94 \$ 1-2$, to ich charakter autonomiczny i wewnętrzny. Po pierwsze są one normami autonomicznymi, endogennymi i nie są narzucone instytucji (podmiotowi), która na mocy potestas statuendi, może regulować obszar swojej własnej autonomii. Przejaw autonomicznego charakteru norm statutowych spotykamy w kan. $117 \mathrm{KPK}$, który implikuje wcześniejsze pochodzenie statutów, w stosunku do

\footnotetext{
${ }^{49}$ Kan. $596 \$ 2$ i 732.

${ }^{50}$ Kan. $295 \$ 1$.

${ }^{51}$ „Ordynariaty wojskowe, które także mogą nazywać się polowymi i które pod względem prawnym zostają upodobnione do diecezji, są okręgami kościelnymi o szczególnym charakterze i rządzą się własnymi, nadanymi przez Stolicę Apostolską statutami”. IoAnnes PAulus PP. II, Constitutio Apostolica Spirituali militum curae [21 aprile 1986] \$1, Acta Apostolicae Sedis 78(1986), s. 481-485; por. P. MARCUZzI, Statuti e regolamenti, s. 539.

${ }^{52}$ Por. tamże, s. 205. R. SoBAŃski pisze: „autonomicznie uchwalone statuty zyskują swą moc z umowy zawartej przez tworzących zespół (statutum conventionale), ich włączenie w porządek prawny Kościoła dokonuje się zgodnie z przepisami prawa przez przejrzenie (np. kan. 299\$3; 451), aprobatę lub zatwierdzenie ze strony właściwej władzy kościelnej”. Komentarz do kan. 94, s. 161. Szerzej na temat interwencji władzy kościelnej w kwestii statutów zob. U. RHode, Die „Recognitio“ von Statuten, Dekreten und liturgischen Büchern, Archiv für katholisches Kirchenrecht 169(2000), nr 2, s. 433-468.

${ }^{53}$ Por. X. Brossa, Régimen jurídico, s. 206.
} 
interwencji władzy kościelnej: zespół osób (korporacja) albo fundacja jako pierwsze wypracowują swoje statuty i następnie, jeśli pragną otrzymać osobowość prawną, ich statuty muszą być zatwierdzone przez kompetentną władzę ${ }^{54}$. Po drugie, normy statutów w sensie właściwym są normami ad intra, czyli wewnętrznymi, które dotyczą jedynie członków korporacji albo fundacji. Są to normy, które regulują system wewnętrzny zespołu osób czy fundacji, i tylko wyjątkowo dotyczą osób trzecich ${ }^{55}$.

Statuty są normami administracyjnymi niezależnymi, przepisami administracyjnymi, odróżniającymi się zarówno od aktu administracyjnego konkretnego (szczególnego) jak i dekretów ogólnych i instrukcji. Odróżniają się od aktów administracyjnych pojedynczych, na podstawie kryterium materialnego, ze względu na treść, jaką posiadają: statuty zawierają deklaracje woli ze skutecznością ogólną i nieosobową, podczas gdy akt administracyjny pojedynczy ma adresata indywidualnego. Co do dekretów ogólnych i instrukcji, różnica znajduje się w funkcji: system normatywny, który ustalają normy statutowe nie jest wykonawczy w relacji do innych ustaw - jak w dekretach ogólnych (wykonawczych) i instrukcjach - lecz niezależny i autonomiczny, chociaż jest poddany zasadzie legalności ${ }^{56}$.

C. Rosell jest zdania, że za każdym razem, kiedy instytucja nie jest korporacją (zespołem osób), ani fundacją (zespołem rzeczy), to zgodnie z kan. 115 trzeba stwierdzić, że jej statuty trzeba rozumieć w sensie niewłaściwym albo szerokim ${ }^{57}$. Według przywołanego kano-

${ }^{54}$ Żaden zespół osób lub rzeczy, pragnący otrzymać osobowość prawną, nie może jej uzyskać, chyba że jego statuty zostały zatwierdzone przez kompetentną władzę. Kan. 117; por. X. Brossa, Régimen jurídico, s. 208.

${ }^{55}$ To oznacza, że mogą dotyczyć osób trzecich, w takiej mierze, w jakiej określają prawa i obowiązki członków, albo uprawnienia organów lub ich przedstawicieli w ich relacjach ad extra. Por. X. Brossa, Régimen jurídico, s. 208.

${ }^{56}$ Por. X. Brossa, Régimen jurídico, s. 210; A. Bettetini, Comentario al can. 94 -95 , s. 705.

${ }^{57}$ Santuarios y Basílicas en el Derecho canónico vigente, Efemérides Mexicana 6(1988), nr 17, s. 178. Kan. $115 \$ 1$. „Osobami prawnymi w Kościele są albo zespoły osób, albo zespoły rzeczy”. 
nisty w KPK z 1983 r. jest mowa także o statutach w sensie szerokim, kiedy prawodawca odnosi się do innych podmiotów nie będących osobami prawnymi, korporacjami czy fundacjami np. stowarzyszenia prywatne wiernych ${ }^{58}$, rada kapłańska diecezji ${ }^{59}$, diecezjalna rada duszpasterska ${ }^{60}$. Ponadto Kodeks mówi także o statutach odnosząc się do kościoła „który nie jest ani parafialny, ani kapitulny, ani złączony z domem wspólnoty zakonnej lub stowarzyszenia życia apostolskiego"61, do projektów "nowych form życia konsekrowanego"62, do katechumenatu ${ }^{63}$ oraz do świętego Kolegium Kardynałów ${ }^{64}$.

Prawa i obowiązki wynikające z przejrzanych, aprobowanych lub zatwierdzonych statutów są prawami i obowiązkami kanonicznymi. W statutach należy określić cel (program, dla którego zespół istnieje), konstytucję (nazwa, siedziba, kształt prawny i struktura, nabycie, charakter i utrata przynależności, prawa i obowiązki), zarząd (skład, zadania, sposób powoływania i odwoływania, sposób podejmowania decyzji, reprezentowanie na zewnątrz, kontrola) oraz sposoby działania (metody, środki, zasięg działalności, stosunek do innych zespołów osób lub rzeczy).

Statuty muszą pozostawać w zgodzie z obowiązującym prawem, respektować prawa nabyte osób trzecich, uwzględniać ewentualne

$\$ 2$. Zespół osób, który może być ustanowiony co najmniej z trzech osób, jest kolegialny, jeżeli jego działanie określają członkowie współdziałający w podejmowaniu decyzji, na równych prawach lub nie, zgodnie z przepisami prawa i statutów; w przeciwnym wypadku jest niekolegialny.

$\$ 3$. Zespół rzeczy, czyli fundacja autonomiczna, składa się z dóbr lub rzeczy duchowych lub materialnych, którymi, zgodnie z postanowieniami prawa i statutów, zarządza jedna lub kilka osób fizycznych albo kolegium”.

${ }^{58}$ Por. kan. 304, 310, 322.

${ }^{59}$ Por. kan. 496.

${ }^{60}$ Por. kan. 513.

${ }^{61}$ Kan. 556; kan. 562.

${ }^{62}$ Por. kan. 605.

${ }^{63}$ Por. kan. $788 \S 3$.

${ }^{64}$ Por. kan. 349 i 833, nr 2; C. Rosell, Santuarios y Basílicas, s. 178. 
dyspozycje fundacyjne oraz mieć wzgląd na wymogi dobra wspólnego Kościoła ${ }^{65}$.

Odnośnie interpretacji statutów rozpatrywanych w kan. $94 \$ 3$ należy stosować się do postanowień kan. 16-21. Jeżeli wspomniane statuty obejmują normy nie zawarte w prawie powszechnym, albo zawierają wyjątek od ustawy, podlegają ścisłej interpretacji ${ }^{66}$. Natomiast ścisła interpretacja narzuca się zawsze wobec dyspozycji przewidzianych w statutach, o których traktuje kan. $94 \$ 1-2$, które trzeba uważać za normy specjalne, jako że odnoszą się tylko do konkretnej instytucji ${ }^{67}$.

\section{Walor prawny statutów kapituły}

Należy zaznaczyć, że w diecezji istnienie kapituły katedralnej i kapituł kolegiackich jest możliwe, ale nie obowiązkowe. Jest to więc instytucja fakultatywna. Dyrektorium o pasterskiej posłudze biskupów “Apostolorum Successores” przypomina, że „erekcja kapituły katedralnej, która nie jest aktem obowiązkowym, dokonywanie w niej innowacji oraz jej zniesienie są zarezerwowane Stolicy Apostolskiej"68. Tym bardziej odnosi się to do kapituł kolegiackich. Kan. $508 \$ 2$ KPK zaznacza, że tam, gdzie nie ma kapituły (katedralnej i kolegiackiej), biskup diecezjalny powinien mianować jakiegoś kapłana do wykonywania zadania kanonika penitencjarza ${ }^{69}$. G. Bier zwraca uwagę, iż pomimo historycznego znaczenia kapituł kanoników, zwłaszcza w Europie, nie są one jednakowo rozpowszechnione w Kościele łacińskim jako całości; kapituły kolegiackie są szczególnie rzadkie ${ }^{70}$. Figura ta nie znajduje się w Kodeksie Kanonów Kościołów Wschodnich ${ }^{71}$.

\footnotetext{
${ }^{65}$ Por. R. Sobański, Komentarz do kan. 94, s. 161-162.

${ }^{66}$ Kan. 18.

${ }^{67}$ Por. A. Bettetini, Comentario al can. 94, s. 709.

${ }^{68}$ AS, nr 187.

${ }^{69}$ Por. AS, nr 188. Zob. J. Krukowski, Komentarz do kan. 503-510, w: Komentarz do Kodeksu Prawa Kanonicznego. T. 2. Ks. II (1). Lud Boży, J. Krukowski (red.), Poznań 2005, s. 401.

${ }^{70}$ Choć w Polsce jest ich stosunkowo dużo.

${ }^{71}$ G. Bier, Cabildo de canónigos, s. 782.
} 
Należy dodać, że kapituła katedralna może być tylko jedna w diecezji, jak jeden jest tylko kościół katedralny, przy którym się ją eryguje. Natomiast kapituł kolegiackich może być kilka ${ }^{72}$.

Kodeks milczy w sprawie osobowości prawnej kapituł kanoników. Ponieważ stanowią one zespół osób erygowany na mocy aktu jurysdykcji, którego członkowie z reguły uczestniczą w decyzjach zgodnie ze statutem, winny być uznawane za publiczne osoby prawne kolegialne. Kan. $115 \$ 2$ postanawia, że zespół osób, który może być ustanowiony co najmniej z trzech osób, jest kolegialny, jeżeli jego działanie określają członkowie współdziałający w podejmowaniu decyzji, na równych prawach lub nie, zgodnie z przepisami prawa i statutów; w przeciwnym wypadku jest niekolegialny ${ }^{73}$. Expressis verbis mówią na ten temat statuty kapituł. Statut Kapituły Metropolitalnej w Kolonii zawiera następujący tekst: „Kapituła Metropolitalna w Kolonii jest kolegialną publiczną osobą prawną prawa kościelnego"74. Statuty Kapituły Katedralnej w Walencji stwierdzają, że „Kapituła Kanoników Katedry Walencji jest kolegium kapłanów posiadającym publiczną osobowość prawną, podlegającym Stolicy Apostolskiej i arcybiskupowi" ${ }^{\prime \prime 5}$, natomiast Statut Kapituly Katedralnej w Tarnowie zawiera następująca dyspozycję: „Kapituła posiada osobowość prawną zarówno w świetle prawa kanonicznego, jak i cywilnego"76.

\footnotetext{
${ }^{72}$ E. Sztafrowski, Prawo kanoniczne w okresie odnowy soborowej podręcznik dla duchowieństwa. Tom pierwszy, Warszawa 1976, s. 390.

${ }^{73}$ Por. G. Bier, Cabildo de canónigos, s. 782; H. CAppello, Los Cabildos de Canónigos, s. 397. Kapituły kanoników są publicznymi kolegialnymi osobami prawnymi prawa kanonicznego i jako takie wymagają ustanowienia przez właściwe władze kościelne, aktem jurysdykcyjnym. W. Aymans, K. Mörsdorf, Kanonisches Recht. Lehrbuch aufgrund des Codex Iuris Canonici, t. 2, Paderborn. München. Wien. Zürich 1997, s. 403.

${ }^{74}$ Statuten des Metropolitankapitels Köln, Präambel, https://www.koelner-dom. de, (dostęp: 4.01.2018).

${ }^{75}$ Estatutos del Cabildo de las i catedral basílica metropolitana de S. María de Valencia (Enero 2007), nr 4, www.catedraldevalencia.es/de/el-cabildo_estatutos. php, (dostęp: 4.01.2018).

${ }^{76}$ Statut Kapituly Katedralnej w Tarnowie [22 grudnia 2001], art. I \$2, Currenda 151 (2001), nr 4, s. 531-539.
} 
Mimo, że instytucja kapituł kanonickich w diecezji nie jest nakazana, to jeśli została ona erygowana, to zgodnie z treścią kan. 505 każda z nich, tak katedralna, jak i kolegiacka, powinny mieć własne statuty. Owe własne statuty stanowią prawo własne kapituły jako osoby prawnej, uchwalone aktem kolegialnym - zgodnie z prawem - przez działanie wszystkich jej członków ${ }^{77}$. Obowiązek posiadania statutów przez kapituły przypominają również prawodawcy partykularni. W Dekrecie nadania kościołowi Przemienienia Pańskiego $w$ Garwolinie tytułu kolegiaty i powołania przy niej Kapituły Kolegiackiej zamieszczono postanowienie: „na mocy kanonu 116, Kapituła z chwilą powstania stanowi publiczną osobę prawną, a jej struktura i funkcjonowanie są określone w zatwierdzonym dzisiaj statucie"78. Natomiast Dekret erekcyjny Kapituły Kolegiackiej Gdyńskiej przy Kolegiacie pod wezwaniem Najświętszej Maryi Panny Królowej Polski w Gdyni stanowi: „w działalności swojej Kapituła Kolegiacka Gdyńska kieruje się zatwierdzonymi przez Arcybiskupa Metropolitę Gdańskiego statutami"79.

Każda kapituła, tak katedralna jak i kolegiacka powinna mieć własny statut, uchwalony poprzez prawny akt kapitulny ${ }^{80}$. Statuty są

\footnotetext{
${ }^{77}$ Por. kan. 119; J. KRukowski, Komentarz do kan. 503-510, s. 397. „W poszanowaniu dla praw fundacyjnych oraz biorąc pod uwagę obyczaje i lokalną tradycję, kapituła opracuje własne statuty, które następnie mają być przedstawione biskupowi do zatwierdzenia”. AS, nr 187. G. READ twierdzi, że biskup w odpowiednich okolicznościach, ma prawo dyspensować od posiadania przez kapitułę statutów, zgodnie z normami regulującymi kwestię dyspens (kan. 85). Commentary to can. 503-510, w: The canon law letter and spirit a practical guide to the code of canon law. Prepared by the canon law society of Great Britain and Ireland in association with The Canadian Canon Law Society, F. Morrisey (ed.), London 1999, s. 280.

${ }^{78}$ Biskup Siedlecki, Dekret nadania kościołowi Przemienienia Pańskiego w Garwolinie tytułu kolegiaty i powołania przy niej kapituły kolegiackiej [20 kwietnia 2011], Wiadomości Diecezjalne Siedleckie 80(2011), nr 7-8, s. 338.

${ }^{79}$ Arcybiskup Metropolita Gdański, Dekret erekcyjny Kapituły Kolegiackiej Gdyńskiej przy Kolegiacie pod wezwaniem Najświętszej Maryi Panny Królowej Polski w Gdyni (26 czerwca 2001), w: J. Więckowiak, Kolegiata i kapituła w Gdyni, Pelplin 2003, s. 42.

${ }^{80}$ Kan. 505.
} 
więc uchwalane przez samą kapitułę. Prawny akt kapitulny (legitimus actus capitularis) to kolegialne działanie kapituły (przez działanie wszystkich jej członków) zgodne z prawem ${ }^{81}$. Statut prawnie uchwalony przez kapitułę i zatwierdzony przez biskupa jest zbiorem norm, którymi kapituła się rządzi. Statut kapituły nie jest ustawą w ścisłym znaczeniu, gdyż kapituła, która go uchwala, nie ma władzy ustawodawczej. Normy statutu mają charakter umowny (normae conveniionales): obowiązują one na podstawie umowy i złożonej przysięgi kanonickiej ${ }^{82}$.

Wyłącznie więc do kapituły należy uchwalenie własnego statutu, chociaż wszelkie jego zmiany i zniesienie wymagają aprobaty biskupa. Statut ten nie jest ustanowiony na mocy autory tetu biskupa jak ustawodawstwo diecezjalne, lecz przez kapitułę jako publiczną osobę prawną, będącą jego autorem ${ }^{83}$. Kwestią dyskusyjną jest to, czy kapituły kanoników, zgodnie z tym, co zostało powiedziane, mają obecnie szeroką autonomię statutową, co jest często utrzymywane. Jest jednak faktem, że prawodawca aktualnego Kodeksu ograniczył liczbę norm odnośnie do statutów kapituł w stosunku do KPK z 1917 r., aby w ten sposób zapewnić kapitułom większą autonomię ${ }^{84}$. Jednak decyzja

\footnotetext{
${ }^{81}$ Jeśli chodzi o „akty kolegialne”, trzeba uwzględnić ustalenia kan. 119, a zwłaszcza to, co nakazuje jego nr 3: „co zaś dotyczy wszystkich jako jednostek, musi być przez wszystkich zaaprobowane”. Zob. F. LozA, Comentario a los cán. 503-510, w: Comentario exegético al Código de Derecho Canónico, A. Marzoa, J. Miras, R. Rodríguez-Ocaña (red.), t. 2, cz. II, wyd. 2, Pamplona 1996, s. 1176.

${ }^{82}$ T. Pawluk, Prawo kanoniczne według Kodeksu Jana Pawła II. Lud Boży jego nauczanie i uświęcanie, t. 2, Olsztyn 1986, s. 246.

${ }^{83}$ Por. G. Read, Commentary to can. 503-510, s. 280. L. Chiappetta pisze: „Każda kapituła, konkatedralna lub kolegiacka, musi mieć swój własny statut. Ich sporządzanie pozostawione jest kapitule, co musi być dokonane poprzez zgodny z prawem akt kapitulny. Oznacza to, że biskup, z racji swojej władzy rządzenia, może ustanowić pewne normy ogólne, które odpowiadają dobru powszechnemu diecezji i dyscyplinie kleru, ale nie może on bezpośrednio lub pośrednio zastąpić Kapituły w jego redagowaniu. Il Codice di Diritto Canonico, s. 598.

${ }^{84}$ Zob. Communicationes 5 (1973), s. 232. Por. G. Bier, Cabildo de canónigos, s. 782. Statuty kapituł mają istotne znaczenie ze względu na fakt, że obecne przepisy kodeksowe tyczące się kapituł kanonickich mają jedynie charakter ramowy, pozostawiając
} 
odnośnie do zatwierdzenia statutów kapituły - jak również wszelka zmiana albo ich uchylenie - potrzebuje approbatio biskupa diecezjalnego, to znaczy, jego aprobaty, a nie tylko prostego oświadczenia (deklaracji), że nie ma do nich zastrzeżeń (recognitio) ${ }^{85}$. To stwarza biskupowi diecezjalnemu szerokie możliwości decydującego wpływania na kształtowanie statutów ${ }^{86}$. Z chwilą uzyskania zatwierdzenia (approbatio) przez biskupa diecezjalnego statuty kapituł otrzymują moc obowiązującą ${ }^{87}$. Wspomniane biskupie zatwierdzenie statutów jest równoznaczne $\mathrm{z}$ ich ogłoszeniem (promulgacją) jako prawa dla kapituły i jej członków ${ }^{88}$.

prawu statutowemu szerokie pole własnej kreatywności. Por. H. CAppello, Los Cabildos de Canónigos, s. 396.

${ }^{85} \mathrm{~Np}$. Statut des Domkapitels zum Hl. Martinus der Diözese Rottenburg-Stuttgarthttps zawiera wzmiankę o aprobacie biskupiej: „Vorstehendes Statut des Domkapitels der Diözese Rottenburg-Stuttgart wurde am 8. Januar 1993 vom Domkapitel beschlossen und am 2. Februar 1993 vom Diözesanbischof genehmigt. Es kann ohne Genehmigung des Diözesanbischofs nicht geändert oder aufgehoben werden (c. 505 CIC)". Statut des Domkapitels zum Hl. Martinus der Diözese Rottenburg-Stuttgarthttps [2. Februar1993], art. 11, recht.drs.de/fileadmin/user_files/117/Dokumente/ Rechtsdokumentation/2/2/4/2/93_06_01.pdf (dostęp: 12.01.2018). Odnośnie zmian w statucie kapituły, które wymagają aprobaty biskupa diecezjalnego: „Kapituła ma prawo wprowadzania zmian w statutach, które po zatwierdzeniu przez biskupa diecezjalnego otrzymują moc zobowiązującą”. Statuty Jarosławskiej Kapituły Kolegiackiej [26 kwietnia 1999], Uwagi końcowe, w: Synod Archidiecezji Przemyskiej 1995-2000. Statuty i aneksy, Przemyśl 2000, s. 202. „Niniejszy Statut nie może być zmieniony ani zawieszony bez zgody Arcybiskupa Metropolity Szczecińsko-Kamieńskiego". Statuty Wolińskiej Kapituły Kolegiackiej [15 października 2008], nr 60, „Prezbiterium. Pismo Urzędowe Diecezji Szczecińsko-Kamieńskiej” 37(2009), nr 1-2, s. 48.

${ }^{86}$ Aprobata, choć konieczna, nie zmienia charakteru statutów, które pozostają wewnętrznymi konstytucjami kolegium kapłanów, którym autorytet biskupa daje swoją aprobatę i zgodę. L. Chi appetta, Il Codice di Diritto Canonico, s. 598.

${ }^{87}$ Por. G. ReAD, Commentary to can. 503-510, s. 280. Kapituła ma więc pewną swobodę w kształtowaniu statutu, jednak jest ona kontrolowana przez biskupa diecezjalnego. Por. A. Seriaux, Droit canonique, Paris 1996, s. 276; H. Cappello, Los Cabildos de Canónigos, s. 397.

${ }^{88}$ Por. F. LozA, Comentario a los cán. 503-510, s. 1177. „Statut wchodzi w życie z dniem zatwierdzenia go przez Arcybiskupa Metropolitę Szczecińsko-Kamieńskiego” 
Choć statuty kapitulne winny posiadać aprobatę prawowitego przełożonego - biskupa diecezjalnego - to jednak może on jej odmówić jedynie ad normam iuris, jeżeli statut narusza normy prawa powszechnego, czy partykularnego lub nie odpowiada prawdziwemu duchowi kapituł kanoników ${ }^{89}$. Biskup diecezjalny mógłby zaaprobować zmianę statutów kapitulnych albo nawet ich zniesienie, jednak musiałaby zaistnieć poważna przyczyna i zgoda członków kapituły (którzy ją podejmują nowym aktem kapitulnym) ${ }^{90}$, np. statuty by się zdezaktualizowały, albo praktyka pokazała, że nie spełniają one swojej roli, czyli nie regulują w sposób odpowiedni działalności kapituły, przez co nie wypełnia ona swoich obowiązków przewidzianych dla niej przez prawo. Stąd biskupi diecezjalni często aprobują statuty kapituł na określony czas, aby w ten sposób zweryfikować ich postanowienia, np. w Statutach Zamojskiej Kapituły Katedralnej zostało zaznaczone: „na mocy kan. 505 KPK zatwierdzam niniejszym dekretem - na okres pięciu lat Statuty Kapituły Katedralnej w Zamościu"91, a w Estatutos del cabildo de la catedral de Huesca stwierdza się wyraźnie, że „niniejszy statut wchodzi w życie ad experimentum po upływie miesiąca od daty jego zatwierdzenia i ogłoszenia przez Prałata. Po dwóch latach konieczne będzie dokonanie przeglądu jego funkcjonowania i przedstawienie ostatecznej wersji tekstu biskupowi"92. Trzeba dodać, że nowy lub zmieniony statut kapituły potrzebuje nowej aprobaty biskupa diecezjalnego.

Statuty Szczecińskiej Kapituły Katedralnej [1 lipca 2008], nr 65, „Prezbiterium. Pismo Urzędowe Diecezji Szczecińsko-Kamieńskiej” 36(2008), nr 7-8, s. 216.

${ }^{89}$ Por. L. Chiappetta, Il Codice di Diritto Canonico, s. 598.

${ }^{90}$ „Statut ten może zostać zmieniony lub uchylony jedynie za zgodą co najmniej pięciu członków Kapituły i za aprobatą biskupa diecezjalnego”. Statuten des Limburger Domkapitels [21 Januar 2015] \$31, https://www.bistumlimburg.de, (dostęp: 4.01.2018). „Zmiana lub uchylenie niniejszego statutu wymaga zgody kapituły na nadzwyczajnym posiedzeniu zgodnie $z$ kanonem $119 \$ \$ 2$ i 3 i podlega zatwierdzeniu przez Arcybiskupa”. Estatutos del Cabildo de la si catedral basílica metropolitana de S. María de Valencia w nr 153. 5.

${ }^{91}$ Statuty Zamojskiej Kapituły Katedralnej [25 marca 1995], Zamość 1995, s. 9.

${ }^{92}$ Estatutos del cabildo de la catedral de Huesca, nr 84, www.diocesisdehuesca. org, (dostęp: 3.01.2018). 
Statuty kapituł muszą ściśle przestrzegać przepisów nowego Kodeksu, być w stanie zachować i zintegrować wiele przepisów dawnych statutów - zawsze zgodnych z nową kodeksową konfiguracją prawną - które niejednokrotnie od stuleci regulują życie kapituły i okazały się użyteczne i owocne dla jej działalności oraz być tak opracowane, aby z biegiem czasu i nabywaniem doświadczenia mogły być udoskonalane, także w świetle tego, co inne kapituły ustaliły i realizowały z powodzeniem i pożytkiem ${ }^{93}$.

Choć, jak wyżej zaznaczono, nie jest to przedmiotem niniejszego opracowania, to korzystne byłoby, aby każda kapituła miała swój regulamin ${ }^{94}$, a jak sugeruje F. Loza nawet własne Dyrektorium Liturgiczne odnośnie do aktów kultu, które są jej podstawową funkcją ${ }^{95}$.

\section{Treść statutów kapituł kanonickich}

Prawodawca powszechny, z pełnym poszanowaniem wewnętrznej autonomii kapituł, pozostawia w ich rękach kluczowy instrument statuty, które kapituły same opracowują, tak aby one same - w ustalonych ramach prawnych - mogły kształtować swoje życie kościelne i działalność. Istnieje zatem szeroki margines dla inicjatywy i kreatywności każdej kapituły, zgodnie z jej specyfiką, tradycjami historycznymi i aktualnymi okolicznościami, zawsze respektując prawo

\footnotetext{
${ }^{93}$ Por. F. Loza, Comentario a los cán. 503-510, s. 1176; H. Cappello, Los Cabildos de Canónigos, s. 396.

94 „Korzystne byłoby opracowanie regulaminów, w których przewidziano by bardziej szczegółowe kwestie dotyczące sposobu funkcjonowania kapituły”. AS, nr 187. „Niniejszy Statut może być uzupełniony regulaminem dotyczącym działalności kapituły katedralnej, który w razie potrzeby może być dostosowywany do aktualnych potrzeb". Statuts du chapitre cathédral de l'Eglise de Fréjus-Toulon [19 mars 2014], art. 17, http://www.chapitre-frejus-toulon.fr, (dostęp: 4.01.2018).

${ }^{95}$ Por. F. LozA, Comentario a los cán. 503-510, s. 1177. Estatutos del Cabildo de la si catedral basílica metropolitana de S. María de Valencia w nr 64 . 3 nakładają na ceremoniarza-liturgistę kapituły obowiązek przygotowywania co roku, w ścisłej współpracy z przewodniczącym Diecezjalnej Komisji ds. Liturgii diecezjalnego Dyrektorium Liturgicznego, a także troskę o jego publikację i rozpowszechnianie. Być może w takim Dyrektorium znajdą się kwestie aktów kultu wykonywanych w katedrze.
} 
powszechne i partykularne, które może ustanowić każda Konferencja Episkopatu ${ }^{96}$.

Kan. 506, mający charakter ramowy, zawiera dane o charakterze ogólnym na temat istotnych elementów, jakie należy uregulować w statutach kapituł kanonickich. Ustawodawca przed określeniem podstawowych elementów statutów w sposób kategoryczny stanowi klauzulę, która świadczy o wielkim szacunku ustawodawcy kanonicznego do ustaw fundacyjnych, traktowanych jako prawa nabyte: "zachowując zawsze ustawy fundacyjne" (dotyczy to na pierwszym miejscu kapituł erygowanych już dawniej). „Poszanowanie dla praw fundacyjnych jest stałą troską prawa kanonicznego. Przy całkowitej restrukturyzacji instytucji prawnej nie będzie rzadkością, że niektóre prawa fundacyjne nie będą zgodne ze stworzoną, nową sytuacją tylko dlatego, że w momencie ich tworzenia sytuacja wyglądała inaczej. $\mathrm{W}$ takim hipotetycznym przypadku, biorąc pod uwagę kategoryczne potwierdzenie poszanowania tych praw, uważamy, że najlepszym i w wielu przypadkach jedynym możliwym sposobem wyjścia jest zwrócenie się do Stolicy Apostolskiej, aby mogła ona podjąć decyzję w tej kwestii" (chodzi o zmianę ustawy fundacyjnej).

W kan. $506 \S 1$ wyliczone są podstawowe elementy, które winny być określone w statucie kapituły. Mają one dotyczyć: a) struktury kapituły oraz liczby jej członków; b) czynności, jakie mają być wykonywane przez kapitułę w zakresie kultu Bożego oraz posługi; c) zebrań kapituły; d) warunków wymaganych do ważności lub godziwości podejmowanych czynności, z zachowaniem przepisów prawa powszechnego; należy uwzględnić także wymogi prawa partykularnego, w szczególności postanowienia konferencji biskupów i biskupa własnej diecezji ${ }^{98}$. Trzeba więc stwierdzić, że prawodawca

\footnotetext{
${ }^{96}$ F. LozA, Comentario a los cán. 503-510, s. 1178.

${ }^{97}$ Tamże, s. 1178-1179. Por. J. Krukowski, Komentarz do kan. 503-510, s. 398.

${ }^{98}$ Por. J. Krukowski, Komentarz do kan. 503-510, s. 398-399; A. Seriaux, Droit canonique, s. 276. „Przepisami, którymi kapituła się rządzi są następujące: a) Kodeks prawa kanonicznego. b) Postanowienia wydane przez Stolicę Apostolską, arcybiskupa i, jeśli są wiążące, również postanowienia Konferencji Episkopatu Hiszpanii”. Estatutos del cabildo de la iglesia catedral de Santa María de Pamplona
} 
kodeksowy w praktyce zezwala na znaczną różnorodność sposobów funkcjonowania różnych kapituł, w zależności od ich statutów, chociaż zawsze należy zachować minimum jednorodności, według postanowień konferencji episkopatu i przepisów wydanych przez własnego biskupa diecezjalnego, który może przydzielić szczegółowe zadania konkretnej kapitule ${ }^{99}$.

Odnośnie struktury kapituły oraz liczby jej członków Statut Kapituły Katedralnej Płockiej postanawia: „Kapituła Katedralna Płocka składa się z czterech prałatur: prepozytura, archidiakonia, dziekania, scholasteria oraz z ośmiu kanonii. Piastującym godności prepozyta i archidiakona przysługuje tytuł infułata"100. Natomiast Estatuto do cabido da sé de Braga stwierdza: „Kapituła składa się z kanoników, z których niektórzy, wyznaczeni są do wykonywania konkretnych urzędów, nazywanych godnościami, a mianowicie: dziekan kantor, archidiakon, scholastyk, skarbnik i archiprezbiter. Kapituła nie podlega numerus clausus. Zaleca się jednak, aby liczba kanoników i godności (Dignidades) nie przekraczała 18, nie licząc emerytów”101, a Statut Kapituły Katedralnej $w$ Kaliszu zarządza, że „Kapituła Katedralna Kaliska składa się: $\mathrm{z}$ kanoników prałatów w liczbie czterech osób, z kanoników gremialnych w liczbie dziesięciu osób, z kanoników honorowych, których liczba jest pozostawiona uznaniu”102.

[19 marzo 2010], art. 6, www.pazycaridad.org/index_htm_files/cabidoestatutos.pdf (dostęp: 3.01.2018).

${ }^{99}$ Codex Kodeks Prawa Kanonicznego, Komentarz. Powszechne i partykularne ustawodawstwo Kościoła Katolickiego. Podstawowe akty polskiego prawa wyznaniowego. Edycja polska na podstawie wydania hiszpańskiego, P. Majer (red.), Kraków 2011, s. 433.

${ }^{100}$ Statut Kapituly Katedralnej Płockiej, w: „Gdzie jest Bóg, tam jest przyszłość”. XLIII Synod Diecezji Płockiej. Prawo partykularne i program odnowy pastoralnej Kościoła Płockiego, nr 6, Płock 2015, s. 395-402.

${ }^{101}$ Estatuto do cabido da sé de Braga [07 Dezembro 2004], art. 4 i 6, http://www. diocese-braga.pt/media/contents/contents_m9pY91/estatuto_cabido.pdf, (dostęp: 3.01.2018).

${ }^{102}$ Statut Kapituly Katedralnej w Kaliszu, w: Pierwszy Synod Diecezji Kaliskiej 2007-2009. Prawo diecezjalne Kościoła Kaliskiego, nr 6, Kalisz 2009, s. 155-160. Należy dodać, że kanonicy honorowi nie są ściśle członkami kapituł kanonickich. 
Statuten des Bischöflichen Domkapitels Mainz określają, że „Kapituła katedralna diecezji Mainz (Moguncja) jest kolegium siedmiu duchownych-prezbiterów diecezjalnych"103. Trzeba dodać, że statut winien określać także naturę kapituły, czy jest ona katedralna, czy kolegiacka.

Gdy idzie o czynności, jakie mają być wykonywane przez kapitułę w zakresie kultu Bożego oraz posługi, to np. Statut Kapituly Katedralnej $w$ Kaliszu stwierdza, że „Kapitułą Katedralną jest kolegium kapłanów, do którego należy: uświetnianie obecnością uroczystych nabożeństw w kościele Katedralnym, pomoc Biskupowi diecezjalnemu w sprawach przez niego zleconych, pełnienie zadań zleconych przez prawo oraz przez niniejsze Statuty"104, Statuty Kapituly Katedralnej Toruńskiej posiadają następującą dyspozycję: „Kapituła Katedralna Toruńska, nazywana dalej także Kapitułą lub kolegium kapitulnym, stanowi kolegium kapłanów, którego zadaniem jest sprawowanie bardziej uroczystych czynności liturgicznych w bazylice katedralnej w Toruniu oraz wypełnianie zadań zleconych jej przez prawo lub przez Biskupa Toruńskiego (por. kan. $503 \mathrm{KPK}$ )"105. Z kolei Statuts du chapitre cathédral de l'Eglise de Fréjus-Toulon precyzuje, że „podstawową misją kapituły jest uwidocznienie Kościoła w akcie oficjalnej modlitwy. Odpowiada ona za wykonywanie „bardziej uroczystych czynności liturgicznych w kościele katedralnym” (kan. 503), bierze aktywny udział w pozaparafialnych ceremoniach pontyfikalnych. W szczególny sposób każdy kanonik będzie również polecał w modlitwie osobistej biskupa, jego osobę i intencje oraz diecezję. Respektując prawa proboszcza i we współpracy z nim, Kapituła

Są nimi jedynie kanonicy tzw. rzeczywiści (gremialni), o których traktuje kan. 509 $\$ 1$. Por. E. Sztafrowski, Podręcznik prawa kanonicznego, t. 2, Warszawa 1985, s. 185. ${ }^{103}$ Statuten des Bischöflichen Domkapitels Mainz [29 Februar 2000], Kap. I \$1, nr 1, https://www.downloads.bistummainz.de (dostęp: 4.01.2018).

${ }^{104}$ Statut Kapituly Katedralnej w Kaliszu, w: Pierwszy Synod Diecezji Kaliskiej 2007 - 2009. Prawo diecezjalne Kościoła Kaliskiego, nr 2.

${ }^{105}$ Statuty Kapituły Katedralnej Toruńskiej [21 października 1992], nr 1, w: Uchwały Pierwszego Synodu Diecezji Toruńskiej. Prawo partykularne Kościoła Toruńskiego, Toruń 2011, s. 181-188. 
zwróci szczególną uwagę na to, aby katedra pozostała punktem odniesienia dla całej diecezji w wypełnianiu posługi duszpasterskiej i liturgicznej"106. Wreszcie to w myśl Statutu Krakowskiej Kapituły Metropolitalnej „celem głównym kapituły jest sprawowanie uroczystych czynności liturgicznych w katedrze wawelskiej, a zwłaszcza troska o szerzenie kultu św. Stanisława i św. Jadwigi Królowej. Szczególnym zadaniem kapituły jest podtrzymywanie religijno-narodowych tradycji i zwyczajów, a zwłaszcza troska o groby królów, biskupów, wieszczów i zasłużonych Polaków spoczywających w katedrze"107.

Statut kapitulny winien także określać sprawę zebrań kapituły. Statuty Kapituły Katedralnej Toruńskiej stanowią, że „Sesje kapitulne. Każdego roku, według ustalonego kalendarza, Kapituła odbywa swoją sesję zwyczajną. Sesje nadzwyczajne Kapituły odbywają się ilekroć, zdaniem prepozyta, zachodzi tego potrzeba, a także na polecenie Biskupa Toruńskiego oraz na umotywowany wniosek przynajmniej ośmiu członków kolegium kapitulnego. Sesje nadzwyczajne odbywają się w miejscu wskazanym przez prepozyta"108. Z kolei zgodnie z brzmieniem Statutu kapituły katedralnej Kościoła Fréjus-Tulon „posiedzenia kapituły złożone $\mathrm{z}$ kanoników tytularnych i honorowych, gdzie tylko pierwsze mają ,głos w kapitule”, odbywają się co najmniej trzy razy w roku, na osobiste zaproszenie i pod przewodnictwem dziekana, bez uszczerbku dla uprawnień biskupa zwołania zebrania i przewodniczenia kapitule"109.

Statuty mają także ustalać warunki wymagane do ważności lub godziwości podejmowanych czynności, z zachowaniem jednak przepisów prawa powszechnego. Np. Statuty Kapituły Katedralnej Toruńskiej przewidują: „uchwały podczas posiedzeń Kapituła podejmuje kolegialnie, zachowując następujące zasady: $1^{\circ}$ gdy chodzi o wybory:

\footnotetext{
${ }^{106}$ Statuts du chapitre cathédral de l'Eglise de Fréjus-Toulon (19 mars 2014), art. 10-11.

${ }^{107}$ Statut Krakowskiej Kapituły Metropolitalnej [8 września 2003] \$ 4, Notificationes e Curia Metropolitana Cracoviensi 141(2003), nr 10-12, s. 245-254.

${ }^{108}$ Statuty Kapituły Katedralnej Toruńskiej, nr 33-35.

${ }^{109}$ Statuts du chapitre cathédral de l'Eglise de Fréjus-Toulon, art. 14.
} 
prawnie zostaje wybrany ten, kto przy obecności większości uprawnionych do głosowania, uzyskał bezwzględną większość głosów; po dwóch głosowaniach bezskutecznych należy głosować na dwóch kandydatów, którzy otrzymali najwięcej głosów, a jeśli takich jest więcej, na dwóch najstarszych wiekiem; jeśli w trzecim głosowaniu obaj kandydaci otrzymali jednakową ilość głosów, za wybranego należy uważać tego, który jest starszy wiekiem (por. kan. $1191^{\circ} \mathrm{KPK}$ ); $2^{\circ}$ gdy chodzi o inne sprawy: wiążąca uchwała zapada - przy obecności większości uprawnionych do głosowania - bezwzględną większością głosów; jeśli jednak po dwóch głosowaniach ilość głosów jest równa, przewodniczący może swoim głosem sprawę rozstrzygnąć (por. kan. $\left.1192^{\circ} \mathrm{KPK}\right) ; 3^{\circ}$ gdy sprawa dotyczy wszystkich jako jednostek musi być zaaprobowana przez wszystkich (por. kan. $1193^{\circ}$ KPK). Głosowanie dotyczące wyborów oraz innych spraw personalnych odbywa się tajnie, dotyczące zaś innych spraw może odbywać się w sposób jawny, przy czym na głosowanie jawne muszą się zgodzić wszyscy obecni na sesji" 110 . Z kolei Statuts du chapitre cathédral de l'Eglise de Fréjus-Toulon zawiera następującą normę: „w zebraniach kapitulnych decyzje podejmowane są większością oddanych głosów. W przypadku równej liczby głosów, głos dziekana liczy się podwójnie (dwukrotnie). Kanonicy mają przestrzegać zasad dyskrecji i tajności zarówno w odniesieniu do podejmowanych decyzji, jak i wyborów"111.

W kan. $506 \$ 2$ ustawodawca zobowiązuje autorów statutu do określenia wynagrodzeń, jakie mają być wypłacane kanonikom, zarówno stale, jak i doraźnie z okazji spełnionej posługi. Jest słuszne na podstawie zasady sprawiedliwości, aby kanonicy otrzymywali pewne wynagrodzenie za sprawowanie urzędu, bez szkody dla tego, do czego są uprawnieni z racji wykonywania innych urzędów kościelnych. Należy zauważyć, że w nowym Kodeksie usunięto skomplikowane zasady dotyczące kapitulnych „dystrybucji”"112, a zniesienie systemu beneficjalnego przez Sobór Watykański II spowodowało zmiany w sytuacji

\footnotetext{
${ }^{110}$ Statuty Kapituły Katedralnej Toruńskiej, nr 36.

${ }^{111}$ Statuts du chapitre cathédral de l'Eglise de Fréjus-Toulon, art. 15.

${ }^{112}$ Por. L. Chinapetta, Il Codice di Diritto Canonico, s. 599.
} 
ekonomicznej kapituł. Jednak prawodawca kodeksowy ustala zasadę, że członkowie kapituł pobierają dochody, zarówno stałe, jak i z racji wykonywania jakiegoś zadania. Wysokość i odpowiednią część (procent) tego wynagrodzenia „określa statut”. Jest to zatem kwestia obowiązkowego określenia statutowego. Jeśli chodzi o wynagrodzenie, trzeba brać pod uwagę: ustawy fundacyjne, przepisy określone w księdze V KPK, a zwłaszcza w kan. 1272; 1279-1289, wszystko to, co zostało ustalone przez odpowiednią Konferencję Episkopatu i ustawodawstwo diecezjalne oraz prawa nabyte. W stosowaniu powyższej dyspozycji należy uwzględnić także odmienne warunki, jakie istnieją w poszczególnych krajach, w kontekście ustawodawstwa państwowego $^{113}$. Np. w świetle Estatutos del Cabildo de la si catedral basílica metropolitana de S. María de Valencia członkowie kapituły mają prawo do godziwego wynagrodzenia, zgodnie z kan. $281 \$ 1$ i 384, pomocy materialnej oraz ubezpieczenia społecznego zgodnie $\mathrm{z}$ kan. $281 \S 1,384$ i $195^{114}$, natomiast zgodnie z brzmieniem $\$ 36$ Statutów Kapituly Metropolitalnej Poznańskiej „podstawą utrzymania każdego kanonika gremialnego jest wynagrodzenie za pracę związaną z funkcją sprawowaną w Archidiecezji Poznańskiej, renta lub emerytura”"115. Identyczne rozwiązanie zawiera $\$ 19$ Statutów Kapituły Kolegiackiej w Lesznie: „podstawą utrzymania każdego kanonika gremialnego jest wynagrodzenie za pracę związaną z funkcją sprawowaną w Archidiecezji Poznańskiej, renta lub emerytura czy świadczenie wynikające z Braterskiej Opieki Kapłańskiej”"16. Z kolei Statut Ełckiej Kapituły Katedralnej stwierdza: „Kanonik celebrujący Mszę św. (...) otrzymuje

\footnotetext{
${ }^{113}$ J. Krukowski, Komentarz do kan. 503-510, s. 399; F. LozA, Comentario a los cán. 503-510, s. 1179; L. Chiappetta, Il Codice di Diritto Canonico, s. 599.

${ }^{114}$ Estatutos del Cabildo de la si catedral basílica metropolitana de S. María de Valencia w nr 101. 2-3.

${ }^{115}$ Statuty Kapituły Metropolitalnej Poznańskiej [14 września 2003] § 36, w: LXIX Synod Archidiecezji Poznańskiej (2004-2008), t. 1, Dokumenty, t. 2. Statuty, Poznań 2008, s. 447-459.

${ }^{116}$ Statuty Kapituły Kolegiackiej w Lesznie [28 grudnia 2004] \$ 19, w: LXIX Synod Archidiecezji Poznańskiej (2004-2008), t. 1, Dokumenty, t. 2. Statuty, Poznań 2008, s. $460-467$.
} 
od Kanonika Kustosza stypendium mszalne w wysokości, jaką ustala miejscowy zwyczaj bądź praktyka codzienna. Kanonik wygłaszający homilię ma prawo do odpowiedniego honorarium, którego wysokość ustala Kapituła, w zależności od zmieniających się warunków życia"'117.

F. Loza zauważa, że ponieważ na mocy kan. 503, podstawową funkcją kapituły jest oddawanie czci Bogu bardziej uroczystym kultem liturgicznym, logiczne jest, aby kanonicy nosili dla wykonywania takiego kultu swoiste i odpowiednie stroje. Na przestrzeni dziejów, gusta i wrażliwość minionych czasów przesadnie „obciążyły” tak

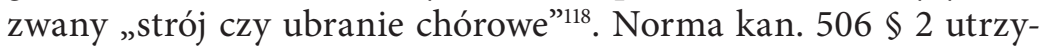
muje wspomniany strój i pozostawia jego określenie statutowi każdej z kapituł, jednocześnie jednak ustala, że musi być on zgodny z „normami wydanymi przez Stolicę Świętą”, dotyczących uproszczenia stroju i insygniów kanonickich. W okresie posoborowym Stolica Apostolska wydała szereg dokumentów normatywnych regulujących kwestię stroju chórowego jednocześnie znosząc przywileje, także stuletnie i niepamiętne, zezwalające kanonikom nie mającym sakry biskupiej na noszenie stroju koloru fioletowego (insygniów i odznak pontyfikalnych $)^{119}$, pozostawiając im prawo do noszenia mucetu koloru czarnego lub popielatego z obszyciem sznurkiem fioletowym ${ }^{120}$. Ostatecznie zezwolono kapitułom zwrócić się do Kongregacji ds. Duchowieństwa - za zgodą swego biskupa - o uzyskanie specjalnego indultu na noszenie mucetu fioletowego w czasie wystąpień w chórze oraz wystąpień in gremio w swoim kościele kapitulnym z okazji różnych uroczystości (zaznaczono równocześnie, że uprawnienia te

\footnotetext{
${ }^{117}$ Statut Ełckiej Kapituły Katedralnej, art. $34 \$ 1-2$, w: I Synod Diecezji Ełckiej 1997-1999, Ełk 1999, s. 174-183.

${ }^{118}$ Comentario a los cán. 503-510, s. 1180.

${ }^{119}$ SaCra Congregatio pro Clericis, Litterae Circulares, De reformatione vestium choralium [30 octobris 1970], nr 1, Acta Apostolicae Sedis 63 (1971), s. 314-315. Fioletowy kolor mucetu jest dopuszczalny tylko w przypadku kanoników z sakrą biskupią. Tamże, nr 2.

${ }^{120}$ De reformatione vestium choralium, nr 2. Zob. T. URRESTI, „Canoncorum insygnia” (can. 506 \$ 2), Revista Española de Derecho Canónico 41 (1985), s. 475-484.
} 
przyznaje się in singulis casibus) ${ }^{121}$. Szaty chórowe mogą być noszone tylko w świątyni (kościele katedralnym lub kolegiackim) podczas celebracji liturgicznych. Poza tymi kościołami dozwolone jest używanie ich tylko przez kanoników, których biskup wyznacza, aby w pewnych okolicznościach reprezentowali go ${ }^{122}$. Kanonicy, którzy posiadają jakiś tytuł honorowy udzielony im przez Stolicę Apostolską, nie mogą używać jako stroju chórowego odznak i insygniów właściwych dla tego tytułu ${ }^{123}$.

T. Pawluk zauważa, że statut kapitulny powinien mieć wstęp historyczny, ukazujący powstanie i rozwój kapituły oraz jej rolę w Kościele partykularnym. Do statutu zwykle dołącza się teksty: aktu

${ }^{121}$ Congregatio pro Clericis, Epistula Praesidibus Conferentiarum Episcoporum missa: in mentem revocantur recentiores normae circa vestes chorales [18 martii 1987], nr 3, Acta Apostolicae Sedis 79 (1987), s. 603-604. „Kapituła Katedralna Ełcka, zgodnie z postanowieniem dekretu erekcyjnego z 21 sierpnia 1992 roku. uwzględnia przepisy odnośnie stroju chórowego kanoników zawarte w Okólniku Kongregacji do Spraw Duchowieństwa z 18 marca 1987 roku. Na strój kanonicki składają się: sutanna koloru czarnego z fioletową obszywką i fioletowymi guzikami, mucet koloru fioletowego, pas koloru fioletowego, biret koloru czarnego z fioletowym pomponikiem oraz komża koloru białego. Kanonicy używają dystynktorium, na którym widnieje wizerunek św. Wojciecha. Biskupa i Męczennika; po jego drugiej stronie herb papieski Jana Pawła II. z datą erekcji Kapituły 1992 roku”. Statut Ełckiej Kapituły Katedralnej, art. $32 \$ 1-3$. Przytoczony Statut powołując się na okólnik z 1987 r. odnośnie stroju chórowego, powinien zaznaczyć, czy kapituła otrzymała indult na używanie mucetu fioletowego w czasie wystąpień w chórze oraz wystąpień in gremio w swoim kościele kapitulnym z okazji różnych uroczystości. Natomiast prawidłowo zredagowana została następująca dyspozycja statutowa: „strój chórowy składa się z sutanny, komży liturgicznej i mozzetta (mucetu) koloru fioletowego zakładanego na komżę. (porównaj zezwolenie Kongregacji ds. Duchowieństwa z 23 stycznia 1987)". Statuti capitolari del capitolo collegiale della basilica di Sant'antonino Martire di Piacenza, Abito corale, www.sant-antonino.it (dostęp: 3.01.2018).

${ }^{122}$ Congregatio pro Clericis, Epistula Praesidibus Conferentiarum Episcoporum missa: in mentem revocantur recentiores normae circa vestes chorales, nr 4.

${ }^{123}$ Congregatio pro Clericis, Epistula Praesidibus Conferentiarum Episcoporum missa: in mentem revocantur recentiores normae circa vestes chorales, nr 5 . Por. F. LozA, Comentario a los cán. 503-510, s. 1180-1181; J. KRUKowsKi, Komentarz do kan. 503-510, s. 399. 
erekcyjnego kapituły, dekretu biskupa diecezjalnego zatwierdzającego statut oraz innych ważniejszych dokumentów dotyczących kapituły ${ }^{124}$.

W kan. 507-508 ustawodawca określa urzędy w kapitule, które winny być uwidocznione w statucie, które mają być sprawowane przez członków kapituły. Nowy Kodeks nie rozróżnia już między „godnościami a „prostymi kanonikami”, mówi jedynie o urzędach. Nie oznacza to, że rozróżnienie to zostało zniesione, ponieważ kan. $507 \S 1$ wyraźnie stanowi, iż takie urzędy mają być tworzone zgodnie z obowiązującymi statutami i z uwzględnieniem zwyczajów lokalnych.

Urzędem expressis verbis wymienionym przez KPK, najważniejszym w kapitule i wymaganym przez prawo, jest stanowisko przewodniczącego kapituły, który stoi na jej czele, kieruje i koordynuje jej działalność ad normam iuris, kieruje posiedzeniami kanoników, kontroluje przestrzeganie statutu i regulaminu, reprezentuje kapitułę i działa w jej imieniu, zgodnie z kan. 118. Nie ma władzy jurysdykcyjnej nad pozostałymi członkami kapituły. Podobnie jak dziekan Kolegium Kardynałów, jest on tylko primus inter pares ${ }^{125}$. Nazwa wymienionego urzędu nie ma znaczenia: może być nazywany przewodniczącym, bądź nadal, zgodnie z tradycyjnym użyciem, nosić nazwę dziekan lub archidiakon ${ }^{126}$. Gdy chodzi o obsadzenie urzędu prepozyta, to przewodniczący może być wybierany przez kapitułę zgodnie

\footnotetext{
${ }^{124}$ T. Pawluk, Prawo kanoniczne według Kodeksu Jana Pawła II. Lud Boży jego nauczanie i uświęcanie, s. 247. Tak jest np. w przypadku Statuts du chapitre cathédral de l'Eglise de Fréjus-Toulon, Historique, czy Statuto del Capitolo Metropolitano della Chiesa Cattedrale di Salerno [6 maggio 2017], http://www.diocesisalerno.it, (dostęp: 3.01.2018).

${ }^{125} \mathrm{Kan} .352 \$ 2$. AS, nr 188.

${ }^{126} \mathrm{~Np}$. proboszcz parafii katedralnej przy bazylice Świętego Antoniego w mieście Piacenza (Włochy) jest jednocześnie Przewodniczącym tamtejszej kapituły. Statuti capitolari del capitolo collegiale della basilica di Sant'Antonino Martire di Piacenza, Composizione. Kodeks nie podaje nazwy urzędu przewodniczącego; różnią się w zależności od lokalnych zwyczajów, np.: Propst, Dekan (niemiecki), deán (hiszpański), provost (angielski), prévôt (francuski). Por. G. BIER, Cabildo de canónigos, s. 783; F. LozA, Comentario a los cán. 503-510, s. 1182. W Polsce nazywa się go często prepozytem. Np. Statut Kapituły Katedralnej Płockiej, art. 9.
} 
z kan. $509 \$ 1^{127}$, bądź może być to urząd nieelekcyjny (niewybieralny) stosownie do kan. $507 \S 1^{128}$, obsadzany na podstawie wolnej decyzji kanoników, którzy tak tę kwestię unormowali w statucie kapituły. W pierwszym przypadku wybór kapituły musi być potwierdzony przez biskupa, $\mathrm{w}$ drugim zaś biskup mianuje bezpośrednio dziekana lub przewodniczącego ${ }^{129}$.

127 „Przewodniczącego Kapituły, czyli Prepozyta, wybierają spośród siebie kanonicy gremialni. Elekta zatwierdza Biskup Diecezjalny (KPK, kan. $509 \$ 2$ )”. Statut Kapituły Kolegiackiej w Wojniczu [9 sierpnia 2014], art. X \$ 3, http://www.wojnicz. diecezja.tarnow.pl, (dostęp: 3.01.2018). Identycznie jest w kapitule katedralnej w Limburgu. Statuten des Limburger Domkapitels, II $\$ 2$, nr 1.

${ }^{128}$ Statut Świdnickiej Kapituły Katedralnej stwierdza: „na czele Kapituły stoi przewodniczący, który nosi tytuł prepozyta. Prepozyta Kapituły mianuje Biskup Świdnicki”. Statut Świdnickiej Kapituły Katedralnej [8 maja 2005], art. 9 \$1-2, Świdnickie Wiadomości Kościelne 2 (2005), nr 3, s. 85-93.

${ }^{129}$ Por. AS, nr 188. L. Chiappetta, Il Codice di Diritto Canonico, s. 599-600; G. Bier, Cabildo de canónigos, s. 783. Przewodniczący kapituły może zostać wybrany przez kapitułę w drodze wyborów. Dopuszczalne są także inne formy desygnacji, jak wyjaśnia Papieska Rada ds. Tekstów Prawnych z autentyczną interpretacją kan. 509 $\$ 1$. Responsiones ad proposita dubia. Patres Pontificiae Commissionis Codici Iuris Canonici Authentice Interpretando propositis in plenario coetu diei 24 Ianuarii 1989 dubiis, quae sequuntur, respondendum esse censuerunt ut infra: D. Utrum praesidis electio imponatur in canonicorum capitulis vi can. $509 \$ 1$. R. Negative. Acta Apostolicae Sedis 81 (1989), s. 991. „Po wysłuchaniu zdania kapituły, do biskupa diecezjalnego, nie zaś do administratora diecezji, należy prawo nadawania wszystkich i poszczególnych kanonikatów, tak w kościele katedralnym, jak i kolegiackim, z odwołaniem wszelkich przeciwnych przywilejów. Tenże biskup zatwierdza wybranego przez kapitułę jej przewodniczącego". W związku z ostatnim zdaniem kanonu powstała wątpliwość, czy mocą tej normy kapituły kanoników mają obowiązek wybierania swego przewodniczącego? Papieska Komisja Interpretacyjna odpowiedziała negatywnie, a jej odpowiedź zatwierdził papież Jan Paweł II dnia 20 maja 1989 r. Zatem wybór przewodniczącego w kapitułach nie jest obowiązkiem kodeksowym, lecz płynie ze statutów (KPK, kan. 507 \$1). Tak więc kan. $509 \$ 1$ nie narzuca systemu wyborczego, jako jedynej formy powołania przewodniczącego; istnieją inne sposoby, w zależności od statutu i istnienia prawomocnych zwyczajów $\mathrm{w}$ regionie, np. kiedy na podstawie prawnego zwyczaju, albo tradycji, czy norm statutowych, wyznaczenie przewodniczącego dokonuje się poprzez swobodne mianowanie przez biskupa, albo urząd ten przypada kanonikowi z najdłuższym stażem w kapitule, lub kandydat jest określony w ustawie fundacyjnej itd. J. Dudziak, 
Odnośnie do obowiązków i praw przewodniczącego, to ustalane są one w statucie kapituły. Np. zgodnie ze Statuts du chapitre cathédral de l'Eglise de Fréjus-Toulon „dziekan (doyen ,czyli przewodniczący kapituły JA) przewodniczy kapitule w chórze i jej zebraniom, ustala harmonogram obrad oraz czuwa nad realizacją podjętych decyzji i przestrzeganiem statutu"130. Z kolei według Statuten des Domkapitels zu Speyer przewodniczący (Dompropst) m. in.: zajmuje pierwsze miejsce w chórze i podczas sesji kapituły, zwołuje członków kapituły katedralnej na sesje kapitulne, ustala porządek obrad, przewodniczy posiedzeniom, głosuje (w przypadku równej ilości głosów) swoim głosem rozstrzygającym, podpisuje protokół z obrad i dba o jego przekazanie biskupowi oraz wykonanie uchwał kapituły. Reprezentuje kapitułę katedralną w kościele katedralnym i poza nim, nadzoruje przestrzeganie statutu zgodnie z kan. $506 \$ 1 \mathrm{KPK}^{131}$. Natomiast Statuti del capitolo cattedrale di Porto-Santa Rufina postanawiają: „przewodniczący kapituły jest odpowiedzialny za: przewodniczenie celebracji Mszy św. w rocznicę poświęcenia kościoła katedralnego; reprezentowanie Kapituły na różnych spotkaniach kościelnych; zwoływanie Kapituły w celu wypełnienia służby chórowej i odbycia posiedzeń kapitulnych"132.

Zgodnie z postanowieniami statutów, według kan. $507 \$ 1$, mają być ustanowione także inne urzędy, biorąc pod uwagę miejscowe zwyczaje (to kolejny dowód na to, że ustawodawca szanuje lokalne tradycje każdej kapituły), których Kodeks nawet przykładowo nie wymienia, jak to czynił poprzedni Kodeks. Do urzędów istniejących tradycyjnie należy zaliczyć: archidiakona, archiprezbitera, magistra, lektora, doktora, prefekta ceremonii, kustosza, teologa, kantora, penitencjarza,

Dziesięcioletni owoc autentycznej interpretacji współczesnego prawa kościelnego, Analecta Cracoviensia 26 (1994), s. 519. Por. G. Bier, Cabildo de canónigos, s. 783; F. LozA, Comentario a los cán. 503-510, s. 1182-1183.

${ }^{130}$ Statuts du chapitre cathédral de l'Eglise de Fréjus-Toulon, art. $13 \$ 1$.

${ }^{131}$ Statuten des Domkapitels zu Speyer [23 August 1990 in der Fassung vom 19 Mai 2009], art. 14, nr 1-4, www.bistum-speyer.de, (dostęp: 4.01.2018).

${ }^{132}$ Statuti del capitolo cattedrale di Porto-Santa Rufina [1 dicembre 1989], art. 11, http://www.diocesiportosantarufina.it, (dostęp: 3.01.2018). 
scholastyka, sekretarza, skarbnika, organistę i dyrektora chóru (w kapitułach hiszpańskich, czy portugalskich), archiwistę, itp. ${ }^{133}$ Należy dodać, że niektóre statuty kapituł rozróżniają urzędy - oficia (penitencjarz, sekretarz, koordynator ceremonii, dyrektor skarbca-muzeum, dyrektor chóru i organista) oraz godności w kapitule (dziekan, kantor, archidiakon, scholastyk, skarbnik i archprezbiter) ${ }^{134}$.

Jedną z najważniejszych funkcji powierzonych członkowi Kapituły jest urząd penitencjarza. Jest to kanonik, który z racji swego urzędu może zwalniać od wielu kar kościelnych bez konieczności odnoszenia się do wyższych autorytetów. Urząd kanonika penitencjarza, tak kościoła katedralnego, jak i kościoła kolegiackiego, imiennie wymieniony w Kodeksie powinien być w każdej kapitule. Winien o nim wspominać statut kapituły. Ma on być mianowany przez biskupa diecezjalnego na wniosek kapituły ${ }^{135}$. Ze względu na swój urząd kanonik penitencjarz posiada „władzę zwyczajną, nie delegowaną” w zakresie wewnętrznym sakramentalnym, której przedmiot obejmuje udzielanie absolucji od grzechów i od cenzur latae sententiae (ekskomuniki, suspensy i interdyktu). Warunkiem udzielenia takiej

\footnotetext{
${ }^{133} \mathrm{~W}$ średniowieczu ukształtowały się w kapitułach następujące godności: prepozyt, dziekan, archidiakon, kantor, scholastyk, kanclerz i kustosz. Każda z tych godności miała określone zadania. Prepozyt zarządzał sprawami majątkowymi, dziekan czuwał nad przestrzeganiem statutów i dyscypliny kościelnej w kapitule, scholastyk nadzorował i prowadził szkołę katedralną, kantor czuwał nad wykonywaniem śpiewów liturgicznych w kościele katedralnym. Kanclerz prowadził kancelarię kapituły i kancelarię diecezji, kustosz brał udział w zarządzie diecezją i miał kompetencje w zakresie jurysdykcji kościelnej. R. WAєCzy , Zarys dziejów kapituły $w$ aspekcie historyczno-prawnym jako organu kolegialnego diecezji do Soboru Trydenckiego, Resovia Sacra 21(2014), s. 476-477. Reguła akwizgrańka św. Chrodeganga, biskupa Metzu (742-766) udoskonalona przez Amalariusz z Metzu (zm. ok. 850), została zatwierdzona przez synod w Akwizgranie w 817 r., wpłynęła na rozwój życia kanonicznego w państwie frankijskim, a następnie niemal w całej Europie. Znała ona jedynie następujące urzędy: proboszcza, czyli prepozyta, scholastyka, kustosza, celerariusza, portariusza i hospitariusza. Por. W. Góralski, Powstanie i rozwój kapituły katedralnej w Płocku, Studia Płockie 5(1977), s. 163.

${ }^{134}$ Tak przewiduje Estatuto do cabido da sé de Braga, art. 4-5.

${ }^{135}$ Kan. 147; 157; 966 i $968 \S 1$.
} 
absolucji jest niedeklarowanie cenzur w formie wyroku lub dekretu ${ }^{136}$ i niezarezerwowanie ich Stolicy Apostolskiej ${ }^{137}$. Nie może więc rozgrzeszać z kar ferendae sententiae i kar ekspiacyjnych ${ }^{138}$. W celu uniknięcia konfliktu między forum wewnętrznym sakramentalnym i forum zewnętrznym urząd penitencjarza jest niekompatybilny $z$ urzędem wikariusza generalnego i wikariusza biskupiego ${ }^{139}$; z natury rzeczy wynika, że jest on niekompatybilny także $z$ urzędem wikariusza sądowego ${ }^{140}$. Kanonik penitencjarz nie może swojej władzy innym delegować. Na terenie diecezji może rozgrzeszać także obcych, a diecezjan również poza diecezją ${ }^{141}$.

Gdy na podstawie kan. $502 \$ 3$, konferencja biskupów zarządzi, by zadania kolegium konsultorów zostały powierzone kapitule katedralnej, wówczas kapituła staje się organem obligatoryjnym i przysługują jej także wszystkie kompetencje (konsultacyjne, kreacyjne i władcze, łącznie z wyborem administratora diecezji) kolegium konsultorów. Kompetencje rady kapłańskiej kapituła katedralna może wypełniać tylko w tych diecezjach, w których konferencja biskupów powierzyła kompetencje kolegium konsultorów kapitule, i tylko wówczas, gdy biskup zgodnie z procedurą rozwiązał radę kapłańską. Kapituła może realizować zadania rady kapłańskiej w sytuacji sede plena tylko przez rok, a w sytuacji sede vacante do jej ustania lub utworzenia rady przez nowego biskupa ${ }^{142}$. Konferencje biskupów powierzyły uprawnienia kolegium konsultorów kapitule katedralnej tylko w tych krajach, w których konkordat gwarantował dla kapituły dotacje pań-

\footnotetext{
${ }^{136}$ Por. kan. $1334 \$ 1 ; 1341-1342$.

${ }^{137}$ Kan.1354 \$3; 1367; $1370 \$ 1 ; 1378 \$ 1 ; 1382 ; 1388 \$ 1 ; 1358$.

${ }^{138}$ Kan. 1336-1338.

${ }^{139}$ Kan. $478 \$ 2$.

${ }^{140}$ Kan. $391 \$ 2$ i $1420 \$ 1-2$. J. Krukowski, Komentarz do kan. 503-510, s. 400-401.

${ }^{141}$ Por. G. Read, Commentary to can. 503-510, s. 282.

${ }_{142}$ M. Sitarz, Kompetencje organów kolegialnych w Kościele partykularnym, Lublin 2008, s. 78. Można powiedzieć, że w nowym KPK kolegium konsultorów powierzone zostały wszystkie pozaliturgiczne funkcje kapituły katedralnej. M. Sitarz. Zadania kolegium konsultorów w sytuacji „sede plena” w KPK z 1983 roku, Roczniki Nauk Prawnych 9 (1999), nr 2, s. 46.
} 
stwowe (m.in. Niemcy, Austria) ${ }^{143}$. Konferencja Biskupów Austriackich (1 lipca1983) i Konferencja Biskupów Niemieckich (podczas jesiennego Zgromadzenia Plenarnego w dniu 19-22 września1983) postanowiły przenieść funkcje Kolegium Konsultantów na kapituły katedralne ${ }^{144}$. Przeniesienie funkcji Kolegium Konsultantów na kapituły katedralne winno być zapisane w statucie kapituł katedralnych ${ }^{145}$.

${ }^{143}$ J. ArRIETA podkreśla, że tylko nieliczne konferencje biskupie Europy centralnej (Austria, Holandia, Luksemburg, itd.) postąpiły zgodnie z kan. $502 \S 3$, podczas gdy wiele innych (Włochy, Hiszpania itp.) całkowicie wykluczyło skorzystanie $\mathrm{z}$ tego uprawnienia, a inne pozostawiły swobodę wyboru poszczególnym biskupom w swoich diecezjach. Diritto, dell'organizzazione ecclesiastica, Milano 1997, s. 436. ${ }^{144}$ Por. N. RuF, Das Recht der katholischen nach dem neuen Codex Iuris Canonici für die Praxis erläutert, Freiburg 1984, s. 138. „Partikularnorm Nr. 6 der Deutschen Bischofskonferenz zu c. $502 \$ 3$ CIC. (Übertragung der Aufgaben des Konsultorenkollegiums auf das Domkapitel). Mit Rücksicht auf die bereits konkordatsrechtlich dem Domkapitel zugewiesenen Aufgaben überträgt die Deutsche Bischofskonferenz gemäß c. 502 \$ 3 CIC die Aufgaben des Collegium Consultorum dem Domkapitel. Fulda, den 22. September 1992, 23. September 1993 und 26. September 1995.

Rekognosziert mit Dekret der Bischofskongregation vom 16. Mai 1995 und 12. September 1995.

Die Partikularnormen erhalten für den Bereich der Deutschen Bischofskonferenz am 1. Januar 1996 ihre Rechtskraft. Gleichzeitig verlieren die von der Deutschen und von der Berliner Bischofskonferenz zu denselben Canones erlassenen Partikularnormen ihre Geltung. Bonn / Mainz, den 5. Oktober 1995 + Karl Lehmann. Bischof von Mainz, Vorsitzender der Deutschen Bischofskonferenz", w: H. Schmitz, F. Kalde, Partikularnormen der deutschsprachigen Bischofskonferenzen (Subsidia ad ius canonicum vigens applicandum 2), Metten 1990, s. $20 \mathrm{f}$.

145 „Grundlage ist die Wiedererrichtung des Metropolitankapitels durch die Bulle „De salute animarum“ vom 16. Juni 1821. Berücksichtigt sind das Statut des Kapitels vom 25. Mai 1928 sowie der Vertrag zwischen dem Heiligen Stuhl und dem Frei-staat Preußen vom 14. Juni 1929 und das Konkordat zwischen dem Heiligen Stuhl und dem Deutschen Reich vom 20. Juli 1933, des weiteren die cann. 503-510 CIC sowie der Beschluss der Deutschen Bischofskonferenz vom 21. September 1983, in dem gemäß can. $502 \$ 3$ CIC die Rechte des Konsultorenkollegiums auf das Metropolitankapitel übertragen wurden (podkreślenie JA)”. Statuten des Metropolitankapitels Köln, Präambel. „O Cabido da Sé de Braga é, por natureza jurídica, um órgão consultivo, que desempenha, em especial, as funções atribuídas pelo cânone $502 \$ 3$ do Código de Direito Canónico ao Colégio de Consultores”. Estatuto do cabido da sé de Braga, art. 3, nr 1. „Das Domkapitel nimmt aufgrund 
Kan. $377 \$ 1$ ustala podstawową zasadę: swobodnego mianowania biskupów przez Biskupa Rzymskiego. Zasada ta została ogłoszona po raz pierwszy jako prawo kościelne w kan. $329 \$ 2$ Kodeksu z 1917 r. Ten sam kan. $377 \$ 1$ ustala również konieczność zatwierdzenia przez Biskupa Rzymskiego tych, którzy zostali prawowicie wybrani na biskupów. Przepis o zatwierdzaniu przez Papieża biskupów wybranych zgodnie $\mathrm{z}$ prawem obecnie obowiązuje w siedemnastu diecezjach, w których kapituła katedralna bierze udział w wyborze biskupa: trzynaście w Niemczech (Akwizgran, Kolonia, Essen, Fryburg, Fulda, Hildesheim, Limburg, Moguncja, Münster, Osnabrück, Paderborn, Rottenburg, Trewir), Salzburg w Austrii oraz Bazylea, Chur i St. Gallen w Szwajcarii ${ }^{146}$. Statuty wymienionych kapituł katedralnych zawierają normy o ich udziale w wyborze biskupów ${ }^{147}$.

Wiele statutów kapituł posiada normy tyczące się mianowania i kwalifikacji kanoników. Na mocy kan. 509 po wysłuchaniu zdania kapituły, do biskupa diecezjalnego, nie zaś do administratora diecezji, należy prawo nadawania wszystkich i poszczególnych kanonikatów, tak w kościele katedralnym, jak i kolegiackim, z odwołaniem wszelkich przeciwnych przywilejów. Godność kanonika powinien nadawać biskup diecezjalny tylko kapłanom odznaczającym się nauką i prawością życia, którzy chwalebnie wypełniają posługę ${ }^{148}$. Należy

des Beschlusses der Deutschen Bischofskonferenz gemäß c. $502 \S 3$ CIC (vom 19. / 22. September 1983) die Aufgaben des Konsultorenkollegiums wahr". Statut des Domkapitels zum Hl. Martinus der Diözese Rottenburg-Stuttgarthttps, art. 2, nr 3. ${ }^{146}$ Por. D. Le Tourneau, Comentario al can. 377, w: Comentario exegético al Código de Derecho Canónico, A. Marzoa, J. Miras, R. Rodríguez-Ocaña (red.), t. 2, cz. II, wyd. 2, Pamplona 1996, s. 719. Szerzej na temat aktualnego wyboru biskupów przez kapituły katedralne zob. M. Mакошsкi, Nominacje biskupów w Kościele katolickim, Warszawa 2007, s. 138-160. M. Rivella, Modalità speciali di designazione di alcuni vescovi, Quaderni di Diritto Ecclesiale 12 (1999), s. 35-45; G. SARZI SARTORI, La designazione del vescovo diocesano nel diritto ecclesiale, Quaderni di Diritto Ecclesiale 12 (1999), s. 7-34. G. BIER, Cabildo de canónigos, s. 784.

${ }^{147} \mathrm{~Np}$. Statuten des Limburger Domkapitels $\$ 21$. Statuten des Metropolitankapitels $K o ̈ l n \$ 39$, gdzie podane są szczegółowe normy wyboru arcybiskupa.

${ }^{148}$ „Zniesienie praw i przywilejów przy nadawaniu urzędów lub beneficjów. Dobro dusz domaga się, ażeby biskup miał odpowiednią swobodę, by mógł właściwie 
zauważyć, że jedynym ograniczeniem, jeśli można tak je nazwać, jest to, że mianowanie członków kapituły winno być poprzedzone konsultacją z kapitułą. Wobec tego, że biskup diecezjalny posiada dużą swobodę w mianowaniu kanoników wydaje się, że może on określić sposób wspomnianej konsultacji: czy np. konsultuje się z całą kapitułą jako organem lub z reprezentatywną liczbą jej członków, niezależnie od tego, czy dotyczy każdej nominacji z osobna, czy też tylko przy okazji ustalania lub zmiany zasady, zgodnie z którą mają być dokonywane nominacje członków kapituły ${ }^{149}$. Trzeba dodać, że sformułowanie kan. $509 \$ 2$, aby mianowany kanonik „chwalebnie wypełniał posługę” zakazuje pośrednio powierzenia kanonikatu młodemu kapłanowi, wyświęconemu niedawno. Intencja prawodawcy jest jasna: chodzi o to, aby gremium kanonickie było ciałem o wysokich kwalifikacjach, składającym się z kapłanów o szczególnym prestiżu, kulturze, świętości życia i doświadczeniu apostolskim ${ }^{150}$.

Dyrektorium o pasterskiej postudze biskupów "Apostolorum Successores” określa, że „do kapituły biskup niech powoła doświadczonych kapłanów odznaczających się nauką i prawością życia, także spośród tych, którzy pełnią znaczące funkcje w diecezji, mając jednak na uwadze, że godności kanonika penitencjarza nie można powierzać wikariuszom generalnym, wikariuszom biskupim oraz krewnym

i sprawiedliwie nadawać urzędy i beneficja, nawet nie duszpasterskie, bardziej godnym duchownym. Paulus PP. VI, motu proprio Ecclesiae Sanctae [6 augusti 1966], art. $18 \$ 1$, Acta Apostolicae Sedis 58 (1966), s. 757-787, tekst polski: Ustrój hierarchiczny Kościoła. Wybór źródeł, W. Kacprzyk Mirosław, M. Sitarz (red.), Lublin 2006, s. 138-155.

${ }^{149}$ Por. G. Read, Commentary to can. 503-510, s. 282. Choć biskup diecezjalny nie ma obowiązku przyłączenia się do opinii kapituły odnośnie określonych kandydatów na kanoników, to jednak mianowanie byłoby nieważne, gdyby nie skonsultował się w ogóle z kapitułą. B. Cusack, Commentary on canons 503-510, w: New Commentary on the Code of Canon Law, edited by J. Beal, New York 2000, s. 665. ${ }^{150}$ Por. L. Chia ppetta, Il Codice di Diritto Canonico, s. 602. L. Chiappetta słusznie zauważa, że chociaż trzeba akceptować dyrektywy kan. $509 \$ 2$, to jednak należy również zauważyć, że dla tego wybranego i wykwalifikowanego gremium kanoników, prawo kodeksowe z pewną niespójnością (niekonsekwencją), powierza jedynie funkcje rytualne i liturgiczne. 
biskupa aż do czwartego stopnia"151. Statuts du chapitre cathédral de l'Eglise de Blois precyzują, że „kapituła katedralna składa się z dwunastu kapłanów cenionych ze względu na ich mądrość doktrynalną, nieskazitelność życia i zasługi zdobyte w codziennym wykonywaniu posługi kapłańskiej”'152, a Statut Łomżyńskiej Kapituły Katedralnej stanowi, że „kanonikiem może być mianowany kapłan wyróżniający się prawością życia, nauką, umiłowaniem Kościoła i godnie wypełniający posługę kapłańską"153, natomiast Statuty Krośnieńskiej Kapituły Kolegiackiej zastrzegają, że „do biskupa diecezjalnego należy mianowanie nowych kanoników Kapituły, po wysłuchaniu jej zdania. Godność tę powinno się nadawać kapłanom odznaczającym się prawością życia i osiągnięciami na polu nauki czy duszpasterstwa"154.

Statuty kapituł zawierają także dyspozycje odnoszące się do sesji kapitulnych, dóbr materialnych, relacji kapituł z parafiami katedralnymi lub kolegiackimi (jeśli taka sytuacja występuje) ${ }^{155}$, określają bliżej zadania kapituły ${ }^{156}$, testament i pogrzeb członka kapituły ${ }^{157}$,

${ }^{151}$ AS, nr 186.
${ }^{152}$ Statuts du chapitre cathédral de l'Eglise de Blois [5 août], art. 1, http://www. catholique-blois.net, (dostęp: 4.01.2018). http://www.catholique-blois.net/eveque/ services-de-l-eveque/conseils-et-commissions/statuts-du-chapitre-cathedral.pdf

${ }^{153}$ Statut Łomżyńskiej Kapituły Katedralnej [5 marca 2000], art. $14 \$ 2$, Łomżyńskie Wiadomości Diecezjalne 62 (2000), nr 1, s. 96-106.

${ }^{154}$ Statuty Krośnieńskiej Kapituły Kolegiackiej [2 sierpnia 2005], st. 10, Kronika Archidiecezji Przemyskiej 91 (2005), nr 3-4, s. 134-141.

${ }_{155}$ Zob. np. Statut Łomżyńskiej Kapituły Katedralnej, art. 20-33.

${ }^{156} \mathrm{~Np}$. „Zadania Kapituły. Sprawowanie bardziej uroczystych funkcji liturgicznych w kościele kolegiackim; Organizowanie pomocy charytatywnej; Troska o formację kapłańską i poziom duszpasterstwa w rejonie janowskim; Propagowanie kultu Matki Boskiej Różańcowej (Łaskawej); Troska o powołania kapłańskie i zakonne; Inspirowanie nowych inicjatyw duszpasterskich; Wspieranie działalności misyjnej Kościoła”. Statut kapituły kolegiackiej pod wezwaniem Matki Bożej Różańcowej przy kościele Świętego Jana Chrzciciela w Janowie Lubelskim [25 lipca 2015], art. II, Kronika Diecezji Sandomierskiej 108 (2015), nr 7-8, s. 417-423.

${ }^{157}$ Statut kapituły kolegiackiej pod wezwaniem Matki Bożej Różańcowej przy kościele Świętego Jana Chrzciciela w Janowie Lubelskim, art. VI. 
objęcie urzędu przez kanonika ${ }^{158}$, precedencji w kapitule ${ }^{159}$, czy wynagrodzenie kanoników za ich posługę ${ }^{160}$.

\section{Podsumowanie}

1. Według ustaleń KPK kapituły kanoników jako korporacje powinny mieć swoje statuty będące wyrazem ich wewnętrznej autonomii, którą ustawodawca powszechny traktuje z wyjątkowym szacunkiem.

2. Mimo, że instytucja kapituł kanonickich w diecezji nie jest nakazana, to jeśli została ona erygowana, to zgodnie z treścią kan. 505 każda z nich, tak katedralna, jak i kolegiacka, powinny mieć własne statuty uchwalone przez samą kapitułę poprzez prawny akt kapitulny.

3. Wyłącznie do kapituły należy uchwalenie własnego statutu, chociaż wszelkie jego zmiany i zniesienie wymagają aprobaty biskupa. Statut nie jest ustanowiony na mocy autorytetu biskupa jak ustawodawstwo diecezjalne, lecz przez kapitułę jako publiczną osobę prawną, będącą jego autorem

4. Statuty kapituł muszą ściśle przestrzegać przepisów nowego Kodeksu, być w stanie zachować i zintegrować wiele przepisów dawnych statutów oraz brać pod uwagę to, co inne kapituły ustaliły i realizowały z powodzeniem i pożytkiem.

5. Kapituły w opracowywaniu statutów posiadają szeroki margines dla własnej inicjatywy i kreatywności, zgodnie z ich specyfiką, tradycjami historycznymi i aktualnymi okolicznościami, zawsze jednak respektując prawo powszechne i partykularne, które może ustanowić każda konferencja episkopatu.

6. Podstawowe elementy, które mają być określone w statucie kapituły winny dotyczyć: struktury kapituły oraz liczby jej członków, czynności, jakie mają być wykonywane przez kapitułę w zakresie kultu Bożego oraz posługi, zebrań kapituły,

\footnotetext{
${ }^{158}$ Np. Statut Ełckiej Kapituły Katedralnej, art. 19-21.

${ }^{159}$ Statuty Krośnieńskiej Kapituły Kolegiackiej, st. 12.

${ }^{160}$ Np. Statut Ełckiej Kapituły Katedralnej, art. 34.
} 
warunków wymaganych do ważności lub godziwości podejmowanych czynności, z zachowaniem przepisów prawa powszechnego. Należy uwzględnić także wymogi prawa partykularnego, w szczególności postanowienia konferencji biskupów i biskupa diecezjalnego.

7. W statucie umieszcza się też sprawę strojów kanonickich, określa się inne urzędy (prócz wymienionych prze Kodeks urzędów przewodniczącego i kanonika penitencjarza), przy uwzględnieniu miejscowych zwyczajów, a także kwestie pełnienia roli kolegium konsultorów i udziału w wyborach biskupów, gdzie takie możliwości istnieją, a także szereg innych kwestii zasygnalizowanych w niniejszym artykule.

\section{Statutes of canonical chapters}

The aim of the article is to present the issue of the statutes of canonical chapters, which should be held by every chapter. The first part portrays the issue of statute as a normative act. The second part examines the legal value of the chapter's statutes, and the third part is dedicated to the issue of the content of the statutes of canonical chapters. The article is summarized and includes references at the end.

SŁOWA KLUCZOWE: kapitała kanoników; kanonik; biskup diecezjalny; statut; liturgia

KEYwORDs: chapter of canons; canon; diocesan Bishop; statute; liturgy

\section{Nota o Autorze:}

Ks. DR HAB. JERZY ADAMCZYK - wykładowca prawa kanonicznego w Wyższym Seminarium Duchownym w Radomiu, członek Stowarzyszenia Kanonistów Polskich. 